\title{
Review Article \\ Study of Modern Nano Enhanced Techniques for Removal of Dyes and Metals
}

\author{
Samavia Batool, ${ }^{1}$ Shatirah Akib, ${ }^{2}$ Mushtaq Ahmad, ${ }^{3}$ \\ Khaled S. Balkhair, ${ }^{4}$ and Muhammad Aqeel Ashraf ${ }^{5}$ \\ ${ }^{1}$ Geology Department, University of Malaya, 50603 Kuala Lumpur, Malaysia \\ ${ }^{2}$ Department of Civil Engineering, University of Malaya, 50603 Kuala Lumpur, Malaysia \\ ${ }^{3}$ Department of Plant Sciences, Quaid-i-Azam University, Islamabad 45320, Pakistan \\ ${ }^{4}$ Department of Hydrology and Water Resources Management, Faculty of Meteorology, Environment and Arid Land Agriculture, \\ King Abdulaziz University, Jeddah 21589, Saudi Arabia \\ ${ }^{5}$ Department of Geology, Centre for Research in Biotechnology for Agriculture, University of Malaya, 50603 Kuala Lumpur, Malaysia
}

Correspondence should be addressed to Muhammad Aqeel Ashraf; aqeelashraf@um.edu.my

Received 16 February 2014; Revised 25 March 2014; Accepted 26 March 2014; Published 20 May 2014

Academic Editor: Fan Dong

Copyright (C) 2014 Samavia Batool et al. This is an open access article distributed under the Creative Commons Attribution License, which permits unrestricted use, distribution, and reproduction in any medium, provided the original work is properly cited.

Industrial effluent often contains the significant amount of hexavalent chromium and synthetic dyes. The discharge of wastewater without proper treatment into water streams consequently enters the soil and disturbs the aquatic and terrestrial life. A range of wastewater treatment technologies have been proposed which can efficiently reduce both $\mathrm{Cr}(\mathrm{VI})$ and azo dyes simultaneously to less toxic form such as biodegradation, biosorption, adsorption, bioaccumulation, and nanotechnology. Rate of simultaneous reduction of $\mathrm{Cr}(\mathrm{VI})$ and azo dyes can be enhanced by combining different treatment techniques. Utilization of synergistic treatment is receiving much attention due to its enhanced efficiency to remove $\mathrm{Cr}(\mathrm{VI})$ and azo dye simultaneously. This review evaluates the removal methods for simultaneous removal of $\mathrm{Cr}(\mathrm{VI})$ and azo dyes by nanomicrobiology, surface engineered nanoparticles, and nanophotocatalyst. Sorption mechanism of biochar for heavy metals and organic contaminants is also discussed. Potential microbial strains capable of simultaneous removal of $\mathrm{Cr}(\mathrm{VI})$ and azo dyes have been summarized in some details as well.

\section{Introduction}

Azo dyes are widely used to dye various materials such as leather, plastics, textiles, food, paper, and cosmetics. Overall production of azo dyes in the world is estimated to be one million tons annually. The use of azo dyes in modern world represents a serious problem worldwide $[1,2]$. Azo dyes are synthetic compounds [1]. These azo dyes can be differentiated by the presence of one or more azo groups $(-\mathrm{N}=\mathrm{N}-)$ as a chromophore which linked different aromatic amines or phenols by a double bond $[1,3]$. More than $10-15 \%$ of applied dyes are released into wastewater during dying process [4]. As fixation of dyestuff on the substrate is not an efficient process, it varies depending upon the method of fixation or level of affinity resulting in production of color water [5], which reduces water quality [6]. As these azo dyes are watersoluble, dyes such as sulfonated azo dyes finally enter into the environment when released through wastewater and have many carcinogenic and mutagenic effects on various forms of life [7]. It affects photosynthetic activity of plants by limiting penetration of sunlight [6]. Moreover, toxic effects of dyes result in formation of tumor, cancer, and allergies in human and also inhibit growth of bacteria, protozoans, algae, plants, and different animals [8].

Various technologies have been applied for removal of azo dyes including physical, chemical, and biological methods but microbial degradation of dye is an efficient tool for removing pollution from environment [5]. Other microorganisms like fungi and algae decolorize dye in waste water by adsorption instead of degradation; as a result, dyes remain in the environment. However, bacteria completely degrade dyes under certain conditions [9]. Even bacteria can degrade intermediate byproduct such as aromatic amines by the hydroxylase and oxygenase enzyme [2]. 
Textile industry effluents with organic pollution often contain heavy metals as well as free ionic metals or in complex form [10]. In biodegradation process, both microbial biomass and its activity are of prime importance. High concentration of heavy metals like $\mathrm{Pb}, \mathrm{Cr}, \mathrm{Cu}, \mathrm{Zn}$, As, and $\mathrm{Cd}$ may have adverse effect on microbial growth and activity [11]. Microbial community composition is sensitive to long term exposure of heavy metals and may affect the decomposition property of microbes [12]. However, toxicity of these metals depends upon their availability or presence in wastewater [13].

Chromium (CrVI) is highly toxic metal that a slight increase in its level results in various environmental and health problems. The United States Environmental Protection Agency (US EPA) has added the $\mathrm{Cr}^{+6}$ in the list of 17 poisoning elements that are major threat to humans, plants, and microorganisms [14]. Industrial effluents are frequently cocontaminated with chromium ions and azo dyes [2]. Toxicity of chromium depends upon its oxidation state chromium 6 which is carcinogenic and highly toxic to all forms of life and it is more mobile and soluble in water while its reduced form chromium 3 is comparatively less toxic as it is insoluble in water [15]. Microorganisms have ability to protect themselves against toxicity of heavy metals by adopting certain mechanisms such as adsorption, uptake methylation, oxidation, and reduction [16]. But excessive concentrations of these metals may negatively influence the microbial activity and its resistant potential to heavy metals. Bacterial resistance to chromate is associated with plasmid or arises from mutation in chromosomes [17].

Chromium constitutes an integral part of many complex azo dyes which are used for dye fixation in wood leather, silk, and paper dyeing industries [18]. The structure of chromium complexes formed through chemical reaction between $\mathrm{Cr}_{2} \mathrm{O}_{3}$ and a variety of azo organic compounds that are very stable and difficult to destroy [19]. Therefore, combining existence of other azo dyes along with chromium is not only adding more contamination in wastewater but also rendering bacterial population.

Shi et al. investigated that $\mathrm{Cr}$ and $\mathrm{Pb}$ have negative impact on soil microbial activity [20]. The effects of $\mathrm{Cr}$ and $\mathrm{Pb}$ were determined in terms of ratio of microbial biomass $C$ to soil organic $\mathrm{C}$, basal respiration per unit microbial biomass $\left(q \mathrm{CO}_{2}\right)$, and the ratio of substrate-response respiration to microbial biomass $\mathrm{C}$ (substrate responsive $q \mathrm{CO}_{2}$ ). The ratio of microbial biomass in $\mathrm{Cr}$ contaminated soil was $0.42 \%$ and in $\mathrm{Pb}$ contaminated soil was $0.36 \%$, while $q \mathrm{CO}_{2}$ and substrate-responsive values were high in $\mathrm{Pb}$ as compared to Cr contaminated soil $(P<0.01)$ which indicates like other heavy metals that $\mathrm{Cr}$ also has stress on bacterial biomass.

It was studied that sulphate reducing bacteria (SRB) removed 25-30\% of initial dye (reactive black B, Ramzol blue, and reactive red $\mathrm{RB}$ ) from medium in $72 \mathrm{~h}$ in the presence of $50 \mathrm{mg} \mathrm{L}^{-1}$ chromium and approximately $95 \%$ of chromium VI removal was achieved at the end of $24 \mathrm{~h}$ incubation period. Results showed that decolorized dye amount was increased at increasing dye concentration by SRB but decolorization yield remained constant [21]. Such lower yield of dye decolorization shows that chromium has inhibitory effect on bacterial efficacy of removing dye. Similarly, Khalid et al. has reported that at $250 \mathrm{mg} \mathrm{L}^{-1}$ of chromium only $8 \%$ decolorization was obtained after $24 \mathrm{~h}$ using $\mathrm{Cr}_{2}\left(\mathrm{SO}_{4}\right)_{3}$ whereas in case of $\mathrm{CrCl}_{3}$ in the same time period at higher concentrations (150$250 \mathrm{mg} \mathrm{L}^{-1}$ ) the decolorization was in the range of 31 to $49 \%$ only [22].

Recently, several microorganisms have been found which have enzymatic system for individual or simultaneous removal of azo dyes and hexavalent chromium (Cr VI) [2, 14, 22, 23]. Bacterial strains KI (Pseudomonas putida) and SL14 (Serratiaproteamaculans) have great potential to reduce simultaneously 93\% CrVI and 100\% decolorization of reactive black-5 azo dye in $24 \mathrm{~h}$ at $\mathrm{pH} 7.2$ and $35^{\circ} \mathrm{C}$ in a batch culture. Individually, $100 \%$ removal of $\mathrm{CrVI}$ and reactive black- 5 dye was obtained in $12 \mathrm{~h}$ by strains KI and SL14 [23].

Biodegradation is an effective cleanup technology used for the removal of organic and inorganic contaminants from soil [24]. Only few aerobic bacterial strains that can utilize azo dyes and heavy metals simultaneously as growth substrates have been isolated. Microbial population proliferates when soil is amended with substances capable of sorption and inactivation of growth inhibiting substances [25].

Biochar has adsorption property which can be produced by thermal degradation of organic materials in the absence of air (pyrolysis). As the pyrolysis temperature increases, the surface area and $\mathrm{pH}$ of the char increase. Large surface area and high cation exchange capacity increase the effectiveness of the char to adsorb organic and inorganic contaminants [26]. Biochar increases not only the sorption of toxic organic and inorganic contaminants in soil but also the other processes related to sorption such as leaching, dissipation, and toxicity for plants [27]. Degradation of azo dye and heavy metals can be obtained by adsorption, enzymatic degradation, or combining both treatment processes [28]. Efficiency of simultaneous degradation treatment for azo dyes and hexavalent chromium can be enhanced by combining different treatment technologies.

Microbial nanotechnology that is a newly emerged method to produce a nanoparticulate catalyst involves the precipitation of transition metals such as palladium, gold, and iron on bacterial cell wall, resulting in the formation of bionano-Met, where Met = transition metal catalyst [29]. On the base of catalytic nature, metal nanoparticles have been applied in environmental remediation [30]. For example, several studies have investigated the application of $\mathrm{Fe}(0)$ nanoparticles to reduce organic and inorganic pollutants [31].

Precipitation of these nanoparticles on bacterial surface increases their degradation potential for pollutants. On availability of electron donor, these nanoparticles tend to catalyze the reduction of contaminants, so rendering them insoluble [32]. A variety of inorganic pollutants such as carcinogenic hexavalent chromium and hexavalent uranium are soluble in their highly oxidized form and become sparingly soluble on reduction (to trivalent chromium and tetravalent uranium in the above case, resp.). On the other hand, several organic compounds such as organic dyes, fertilizers, pharmaceutical 
compounds, and intermediates undergo reductive degradation. In all these cases, the contamination levels in the subsurface environment and their downstream flow can be considerably controlled and managed. In this way, study of various useful cleanup technologies is of major concern.

\section{Azo Dyes}

2.1. Classification of Azo Dyes. Dyes exhibit considerable structural diversity and can be classified by their chemical structure or their application to the fiber type. Dyes must carry one or more functionalities giving the dye color, called chromophores, as well as an electron withdrawing or donating substituents that cause or intensify the color of the chromophores, called auxochrome. The chromophore group can be a base for dye classification. The most important chromophores are azo $(-\mathrm{N}=\mathrm{N}-)$, carbonyl $(-\mathrm{C}=\mathrm{O})$, methine $(-\mathrm{CH}=)$, nitro $(-\mathrm{NO} 2)$, and quinoid groups. The most important auxochromes are amine $(-\mathrm{NH} 3)$, carboxyl $(-\mathrm{COOH})$, sulfonate $(-\mathrm{SO} 3 \mathrm{H})$, and hydroxyl $(-\mathrm{OH})$ groups [33]. Based on the origin and complex molecular structure, dyes can be classified into three categories: (1) anionic: acid, direct and reactive dyes; (2) cationic: basic dyes; and (3) nonionic: disperse dyes [34]. Among the various classes of dyes, reactive dyes are one of the prominent and most widely used types of azo dyes and are too difficult to eliminate. They are extensively used in different industries, including rubber, textiles, cosmetics, paper, leather, pharmaceuticals, and food [35-37]. The most common group reactive dyes are azo, anthraquinone, phthalocyanine [38], and reactive group dyes $[39,40]$. Most of these dyes are toxic and carcinogenic [41]. Dyes may also be classified according to their solubility into soluble dyes like acid, basic, metal complex, direct, mordant, and reactive dyes or insoluble dyes including sulfur, azoic, vat, and disperse dyes.

Almost $109 \mathrm{~kg}$ of dyes is produced annually in the world, of which azo dyes represent about $70 \%$ by weight [42]. Because such large quantities of azo dyes are being produced and used daily by leather tanning, textile, paper production, food industry, and so forth, and they are known to transform to carcinogenic aromatic amines in the environment, their incorrect disposal is a major environmental concern and can affect human and animal health [43].

2.2. Reduction of Azo Dyes. The detailed brief method for the reduction of azo dyes is shown in Figure 1.

\section{Simultaneous Removal Methods}

Physicochemical processes were usually inefficient costly and not feasible to a wide range of dye wastewater [44]. However, biological processes, such as biodegradation, bioaccumulation, and biosorption are more favorable due to cost effectiveness, ability to produce less sludge, and environmental benignity [44-46]. Biosorption and bioaccumulation are the two main technologies in biological process for of dye bearing industrial effluents. They possess good potential to replace conventional methods for the treatment of dyes industry

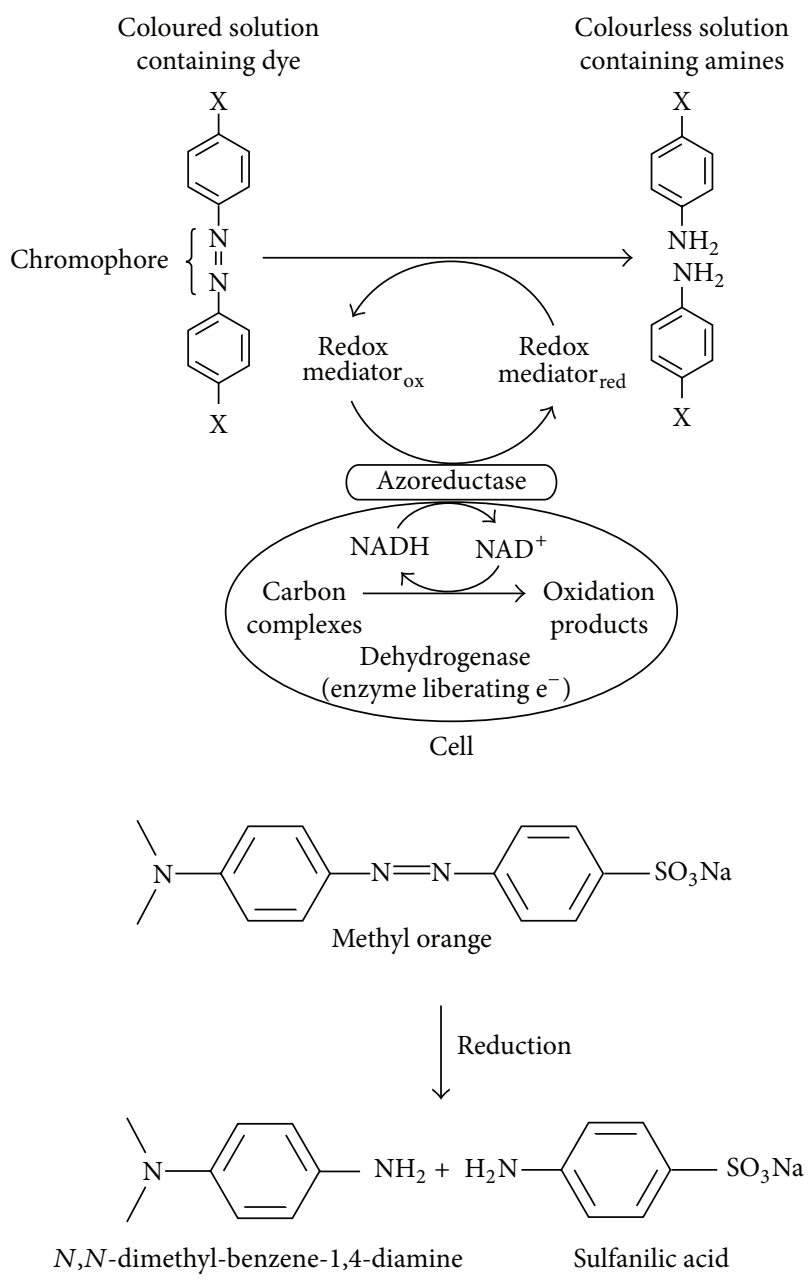

[Reaction 1]

Figure 1: Flow sheet diagram for reduction process of azo dyes.

effluents [47]. Biological process can be carried out in situ at the contaminated site; these are usually environmentally benign, that is, no secondary pollution, and they were cost effective. These are the principle advantages of biological technologies for the treatment of dye industry effluents. Hence, in recent years, research attention has been focused greatly on biological methods for the treatment of effluents $[36,48]$. The disadvantage of this degradation process is that it suffers from low degradation efficiency or even no degradation for some dyes $[1,5]$ and practical difficulty in continuous process [36]. Biosorption can be defined as the passive uptake of toxicants by dead or inactive biological materials. The important advantage of biosorption over bioaccumulation process is that the use of living organisms is not advisable for the continuous treatment of highly toxic effluents. This problem can be overcome by the use of dead biomass, which is flexible to environmental conditions and toxicant concentrations.

3.1. Simultaneous Removal by Biochar. Biochar is increasingly receiving attention as a promising functional material in 
environmental and agricultural application. It refers to the C-rich residues of incomplete combustion of biomass under oxygen-limited conditions and at relatively low temperatures $\left(<700^{\circ} \mathrm{C}\right)$. Various plant tissues and organic-rich wastes including wood chips, animal manure, and crop residues have been used for biochar production. Biochar is produced as a soil amendment for agricultural and environmental gain, which distinguishes it from other carbonaceous products such as activated C (AC) and charcoal [49]. For example, AC is produced from biomass at high temperatures followed by an activation process to increase its surface area for use in industrial processes such as filtration [50].

Extensive work has been done on biochar to slow global warming by sequestering $\mathrm{C}$ from atmosphere into soil [33, 49, 51]. Plants absorb atmospheric $\mathrm{CO}_{2}$ through photosynthesis and store it in their biomass. By heating under oxygen limited condition and at relatively low temperatures, $30-50 \% \mathrm{C}$ in the biomass is converted to stable biochar, which is primarily composed of condensed aromatic C [49]. Incorporation of biochar into soil has the potential to lock atmospheric $\mathrm{C}$ in the solid phase for hundreds to thousands of years [46, 49]. Application of biochar to soil can also help improve soil properties and enhance soil quality by retaining higher moisture and nutrients and microbial activity and therefore increasing crop production [52-54]. Application of biochar to contaminated soils can also reduce the bioavailability of organic contaminants to plants, microbes, and earthworms in contaminated soils [55-57]. The large surface area and high microporosity of biochar are responsible for its high affinity for organic contaminants and large $\mathrm{P}$ content is responsible for removal of heavy metals as well (Table 1) [58].

Recently, several studies have been conducted which shows that biochar affects the transport and fate of organic contaminants in soils [55-60]. Hilton and Yuen were the scientists who determined the sorption of pesticide by ashes obtained from burning crop residue even after washing out organic matter with $\mathrm{H}_{2} \mathrm{O}_{2}$ in 1960s [61]. Addition of wheat straw derived biochar to soil effectively sorbed diuron [56]. Yu et al. indicated that the biochar produced from wood chips was effective in immobilizing chlorpyrifos and carbofuran insecticides in a soil [55].

A study conducted by Cao et al. represents that after 210 days of incubation, biochar (P-rich dairy manure) addition reduced atrazine concentration in $\mathrm{CaCl}_{2}$ extract by $66-81 \%$ in both types of soil (Figures 2(a) and 2(b)) [58]. Similarly, atrazine concentrations in the TCLP extract was reduced by 53-77\% (Figures 2(c) and 2(d)).

A similar experiment was also performed by application of $\mathrm{Pb}$ and biochar in both types of soil. After 120 days of incubation biochar reduced $\mathrm{Pb}$ in $\mathrm{CaCl}_{2}$ extracts by $65-75 \%$ in the SR soil and by $57-68 \%$ in the BR soil (Figures 3(a) and $3(\mathrm{~b}))$. Similarly, $\mathrm{Pb}$ in the TCLP extract was reduced by $72-89 \%$ in the SR soil and by $70-79 \%$ in the BR soil (Figures 3(c) and 3(d)). Rate of reduction of atrazine and $\mathrm{Pb}$ was amplified with increasing biochar level and duration of incubation (Figures 2 and 3).

Mechanism for stabilization of $\mathrm{Pb}$ in soil involves the conversion of less stable $\mathrm{PbCO}_{3}$ into more stable $\mathrm{Pb}_{5}\left(\mathrm{PO}_{4}\right)_{3} \mathrm{OH}$ by $\mathrm{P}$ present in biochar, while adsorption of atrazine on organic $\mathrm{C}$ in biochar may be responsible for immobilization of atrazine in soil [56].

Phosphorus originally contained in the biochar induced conversion of less stable $\mathrm{PbCO}_{3}$ to more stable $\mathrm{Pb}_{5}\left(\mathrm{PO}_{4}\right)_{3} \mathrm{OH}$ and is responsible for soil $\mathrm{Pb}$ immobilization, whereas atrazine stabilization may result from its adsorption on organic C in biochar (Figure 4) [60].

It was investigated by Han et al. that rice straw biochar has great potential to adsorb cadmium (Cd) and sulfamethoxazole (SMX) from cocontaminated water [62]. The calculated maximum adsorption parameter $(Q)$ of Cd was similar in single and binary systems (34129.69 and $35919.54 \mathrm{mg} \mathrm{kg}^{-}$, resp.). However, the Q of SMX in a binary system (9182.74 $\mathrm{mg} \mathrm{kg}^{-}$) was much higher than that in a single system $(1827.82 \mathrm{mg}$ $\mathrm{kg}^{-}$).

3.1.1. Sorption Mechanism. The good fit of the Langmuir adsorption isotherm was based on monolayer coverage of the adsorbate on the surface of the adsorbent, indicating that the sorption of $\mathrm{Cd}$ on rice straw biochar is monolayer sorption on a fixed number of surface sites on the biochar [63]. It was investigated by several experiments that large surface area (SA) is responsible for improving sorption capacity of biochar for heavy metals such as $\mathrm{As}, \mathrm{Pb}, \mathrm{Cu}, \mathrm{Zn}$, and $\mathrm{Cd}$, which provides more surface sites for their adsorption. For example, corn straw char produced at $600^{\circ} \mathrm{C}$ has a larger SA than hardwood char produced at $450^{\circ} \mathrm{C}$, leading to greater adsorption capacities of corn straw char for $\mathrm{Cu}$ and $\mathrm{Zn}$ [64]. However, in a study conducted by Han et al., different diameters showed no significant effect on the sorption of Cd on biochar, regardless of the presence of SMX (Figure 5) [62]. $\mathrm{Xu}$ et al. stated that, in case of adsorbent having low SA $\left(5.61 \mathrm{~m}^{2} \mathrm{~g}^{-}\right)$, sorption may not be influenced by SA of biochar [65]. Therefore, the maximum adsorption capacity of rice straw biochar for Cd calculated by the Langmuir model was similar to the result of the study by Xu et al., which shows that formation of metal-phosphate and carbonate precipitates on the surface of biochar may be attributed to the large adsorption capacity of dairy manure-derived biochar for $\mathrm{Cd}$ (32036.85 $\mathrm{mg} \mathrm{kg}^{-}$) [66]. It was also described by Echeverría et al. that precipitation plays a vital role in the sorption of $\mathrm{Cd}$ by adsorbents. In our study, the amount of adsorption was also extraordinarily large [67], and the SEM images (Figure 5) of rice straw biochar after $\mathrm{Cd}$ adsorption reveal the precipitates on the surface of the biochar, which confirms that precipitation was responsible for adsorption process.

It was suggested by Harvey et al. that $\mathrm{Cd}$ sorption takes place through cation-exchange on biochars produced at $<350^{\circ} \mathrm{C}$, but primarily by two distinctive cation- $\pi$ bonding mechanisms on biochars produced at $\geq 350^{\circ} \mathrm{C}$ [68]. Han et al. produced the rice straw biochar at $400^{\circ} \mathrm{C}$, which indicates that $\mathrm{Cd}^{2+}-\pi$ bonding may contribute to sorption [62]. Sorption of Cd may also be attributed to hydrogenbonding because of the presence of hydroxyl $(-\mathrm{OH})$ in biochar, indicated by the band at $3374 \mathrm{~cm}^{-1}$ [64]. Besides electrostatic interaction, ion exchange could also contribute to $\mathrm{Cd}$ sorption on rice straw biochar. 
TABLE 1: Adsorption of heavy metals and organic contaminants by biochar.

\begin{tabular}{|c|c|c|c|c|c|c|c|}
\hline \multirow[t]{2}{*}{ Type of biochar } & \multirow{2}{*}{$\begin{array}{l}\text { Organic } \\
\text { compounds }\end{array}$} & \multirow[t]{2}{*}{ Heavy metals } & \multicolumn{2}{|c|}{$\begin{array}{l}\text { Maximum adsorption capacity } \\
(\%) / \mathrm{mg} \mathrm{kg}^{-}\end{array}$} & \multicolumn{2}{|c|}{$\begin{array}{l}\text { Time for maximum adsorption } \\
\text { (days) }\end{array}$} & \multirow[t]{2}{*}{ References } \\
\hline & & & O.C. & Heavy metals & O.C. & Heavy metals & \\
\hline Rice straw & $\begin{array}{l}\text { Sulfamethoxazole } \\
\text { (SMX) }\end{array}$ & $\mathrm{Cd}(\mathrm{III})$ & $9182.74 \mathrm{mg} \mathrm{kg}^{-}$ & $35919.54 \mathrm{mg} \mathrm{kg}^{-}$ & - & - & {$[62]$} \\
\hline Wheat straw & Diuron & - & - & - & - & - & [56] \\
\hline $\begin{array}{l}\text { P-rich dairy } \\
\text { manure }\end{array}$ & Atrazine & $\mathrm{Pb}(\mathrm{II})$ & $66-81 \%$ & $72-89 \%$ & 210 days & 120 days & [58] \\
\hline Wood chip & $\begin{array}{l}\text { Chlorpyrifos and } \\
\text { carbofuran } \\
\text { insecticides }\end{array}$ & - & - & - & - & - & [55] \\
\hline Corn straw & - & $\mathrm{Cu}(\mathrm{II}), \mathrm{Zn}(\mathrm{II})$ & - & - & - & - & [74] \\
\hline
\end{tabular}

However, in case of organic contaminant SMX, a positive correlation was found between SA of biochar and the concentration of SMX adsorbed on biochar and the biochar having large diameter $(150-250 \mu \mathrm{m})$ was found to attain maximum adsorption capacity for SMX. Scanning electron microscopy (SEM) and the Fourier transform infrared spectroscopy (FTIR) showed that the removal of Cd and SMX by rice straw biochar may be attributed to precipitation and the formation of surface complexes between Cd or SMX and carboxyl or hydroxyl groups.

Because of amino functional groups and $N$-heteroaromatic rings, SMX is a strong $\pi$-acceptor compound [69]. The mechanism of $\pi-\pi$ electron donor-acceptor (EDA) [70] facilitates the strong interaction between nitro aromatics and black carbon (char) [71]. In the FTIR spectrum, the $\pi-\pi$ EDA interaction between SMX and biochar is because of the COO- groups $\left(1587 \mathrm{~cm}^{-1}\right)$ in rice straw biochar.

3.1.2. Effect of pH on Sorption of Heavy Metals. Heavy metal sorption on biochar is positively correlated with $\mathrm{pH}$ of medium [62]. Negative charge on the surface of the biochar increases with the increase in solution $\mathrm{pH}$ from 3 to 5 . Thus, the enhanced electrostatic attraction could promote adsorption of cationic heavy metals on the negatively charged surface of the biochar. There is also competition between protons and metal cations for sorption sites on the surface of the biochar [72].

It was pointed out, in a study conducted by [62], that the amount of $\mathrm{Cd}$ adsorption increased with increasing $\mathrm{pH}$ and became stable after $\mathrm{pH} 5$ in both single and binary systems. As the $\mathrm{pH}_{\mathrm{zpc}}$ (zero point of charge) of biochar lies between 2.0 and 3.5 [73], the surface charge of biochar in the solution was mainly negative in the $\mathrm{pH}$ range $(3,4,5,6$, and 7.5$)$ in this experiment. When the $\mathrm{pH}$ was above 5 , adsorption capacity started decreasing because of the formation of hydroxide complexes [64]. Chen et al. and Liu and Zhang have revealed similar outcomes, regardless of the original material of the biochar $[74,75]$.

3.1.3. Effect of $p H$ on Sorption of Organic Contaminants. A negative correlation exists between sorption of organic compounds and $\mathrm{pH}$ of solution. Increase in $\mathrm{pH}$ results in the reduction of neutral species, whereas anionic species increases, and it creates a strong electrostatic repulsion between the negatively charged biochar surface and organic anionic species. The cationic, neutral, and anionic species of SMX dominate at $\mathrm{pH}$ values of $<1.7$, around 3.7 , and $>5.7$, respectively [76]. This is the most possible reason that the amount of SMX sorption on biochar increased as $\mathrm{pH}$ value of solution decreased and it was negatively correlated with the $\mathrm{pH}$ values [62].

Moreover, there is strong negative correlation between amount of organic pollutant on biochar and solubility of that contaminant in solution. When $\mathrm{pH}$ rises, it may cause less solubility of organic complex and results in reduction of hydrophobic partitioning between organic complex and biochar, supporting that mechanism of hydrophobic partitioning plays a vital role for sorption of organic compounds on biochar. Therefore, sorption of SMX on rice straw biochar decreased on rising $\mathrm{pH}$ value (3-7.5) [62]. In addition, by increasing $\mathrm{pH}$ value, the $\pi$-acceptor ability would increase with protonation, resulting in weaker interaction of $\pi-\pi \mathrm{EDA}$ between SMX and biochar. This is the one possible reason that sorption level was maximum at $\mathrm{pH} 3$ [62].

3.1.4. Effect of Heavy Metals on Sorption Capacity of Biochar for Organic Contaminants. Earlier studies revealed that either antagonistic [77] or synergistic [78] interaction exists between heavy metals and organic compounds. In the cocontaminated solution, positively charged heavy metals would influence the sorption of organic compounds by altering the biochar surface. Cations could first be adsorbed on the surface of the biochar, and the negative charge on the surface of the biochar would be diminished [79]. Then, the electrostatic repulsion between the biochar surface and anionic organic compounds could be mitigated and therefore significant promotion of adsorption of organic compound. Adsorption of cations $\left(\mathrm{Cd}^{+2}, \mathrm{Ca}^{+2}, \mathrm{Mg}^{+2}\right.$, and $\left.\mathrm{Cr}^{+6}\right)$ could lead to the formation of a bridge on the surface of the biochar [80], assisting the adsorption of organic compound. Deposition of cations on biochar surface could reduce the competition between organic compounds and water for sorption sites by declining the hydrophobicity of the local region [81]. This process not only altered the biochar surface but also formed a 


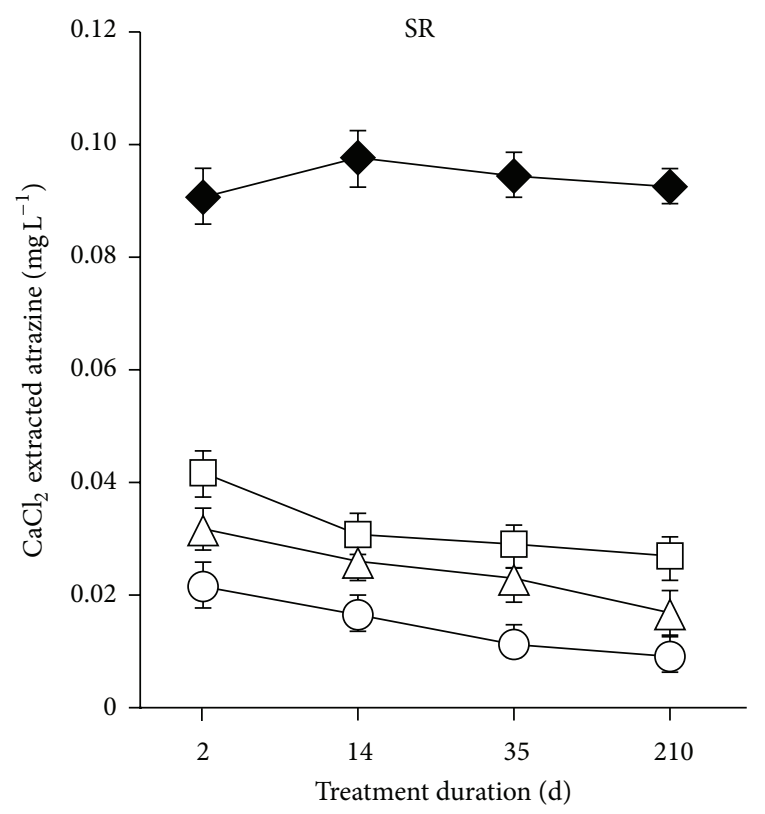

(a)

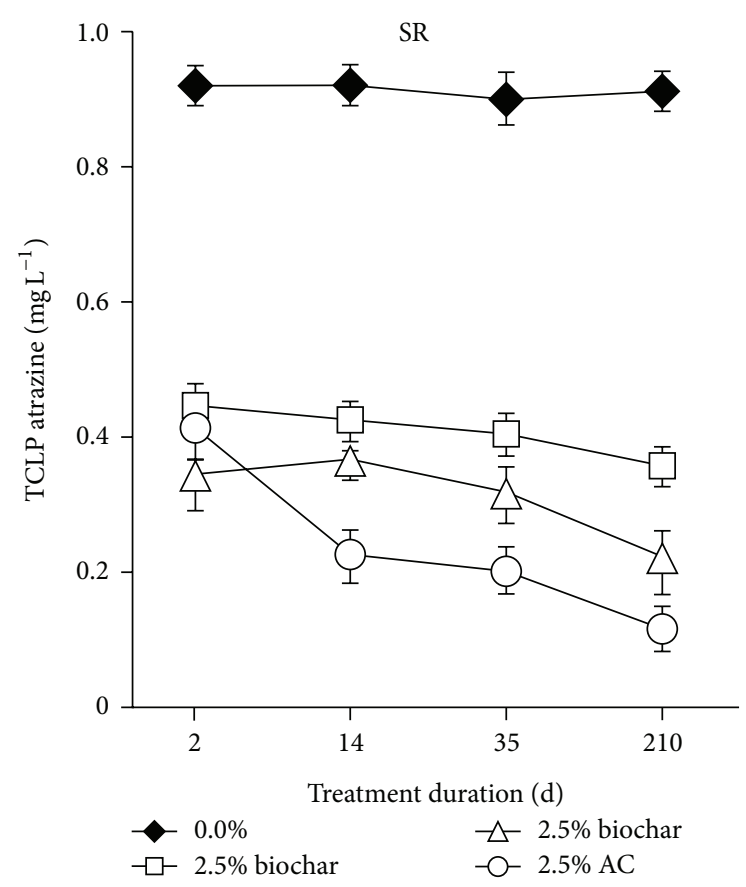

(c)

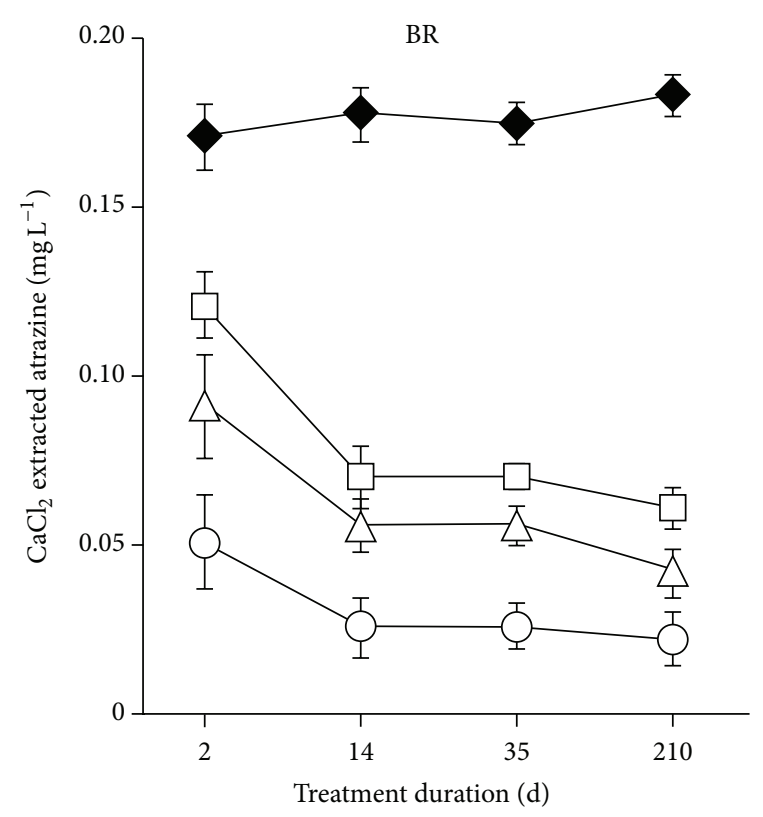

(b)

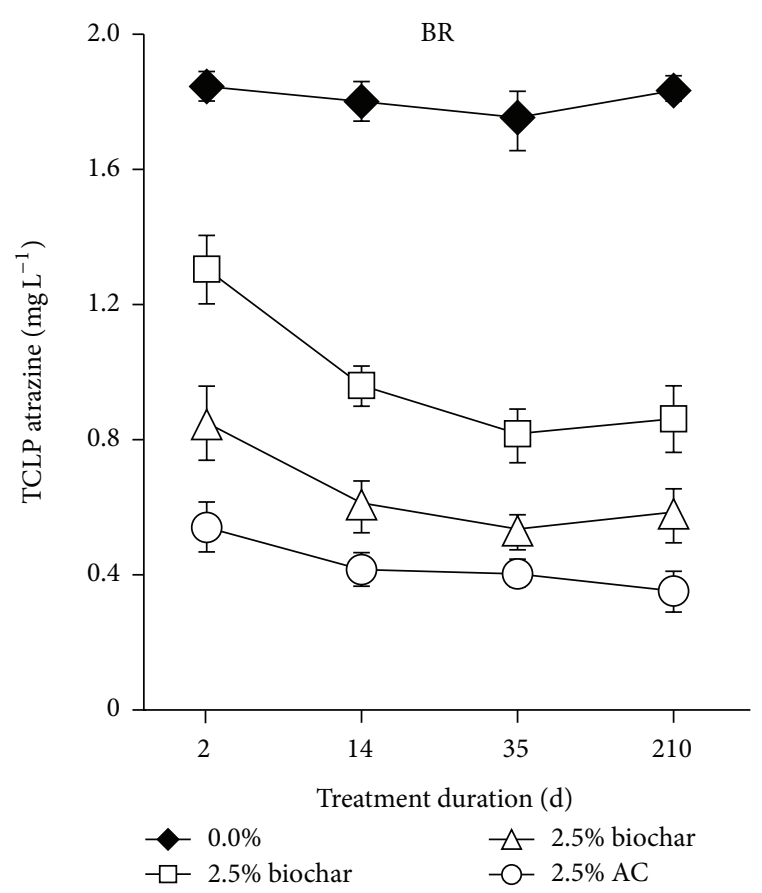

(d)

FIgURE 2: Atrazine concentration in the $\mathrm{CaCl}_{2}$ and TCLP extract obtained from soils treated with different doses of biochar.

heavy metal-organic compound complex [82] with a higher sorption affinity on biochar than SMX, based on the metal complexes [83]. A significant increase of SMX sorption on rice straw biochar by $\mathrm{Cd}$ was reported by Han et al. (Figure 5) [62].

3.2. Simultaneous Removal by Nanotechnology. In order to solve the problem of water and soil pollution, quick and major improvements in wastewater treatment have been conducted, comprising photocatalytic oxidation, adsorption/separation processing, and bioremediation; see Table 4 [83]. However, these treatments have been constrained because of many issues such as processing efficiency, operational method, energy requirements, and economic benefit. Currently, nanomaterials (NMs) have been recommended as efficient, costeffective, and environmental friendly substitute to existing 


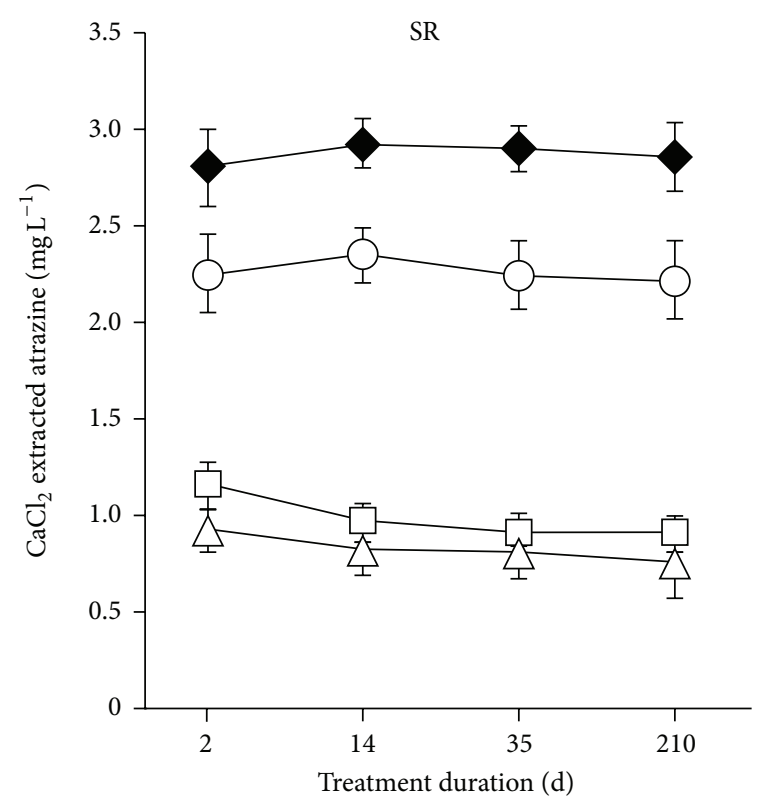

(a)

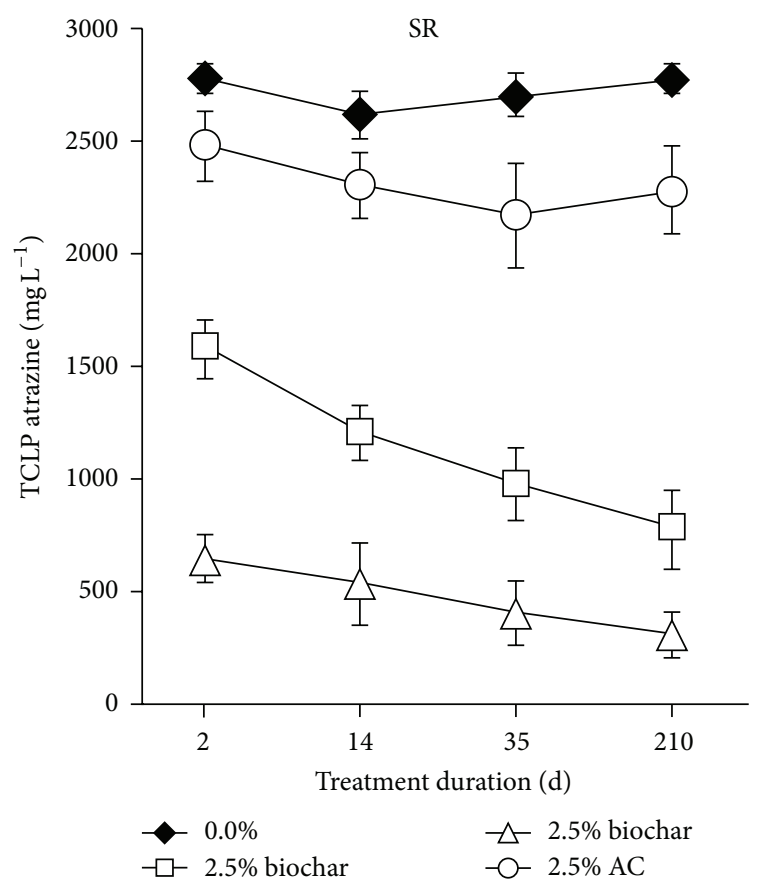

(c)

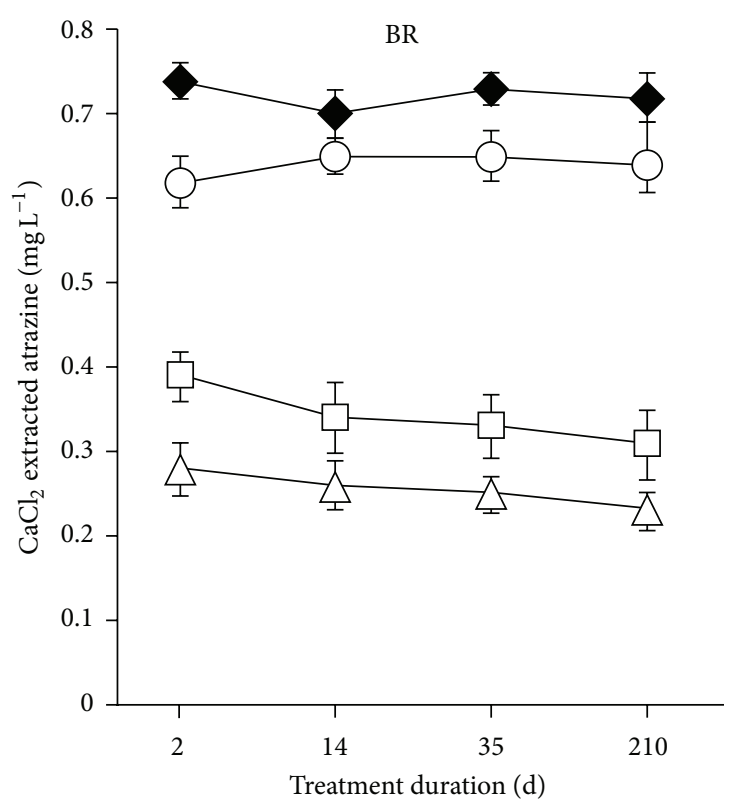

(b)

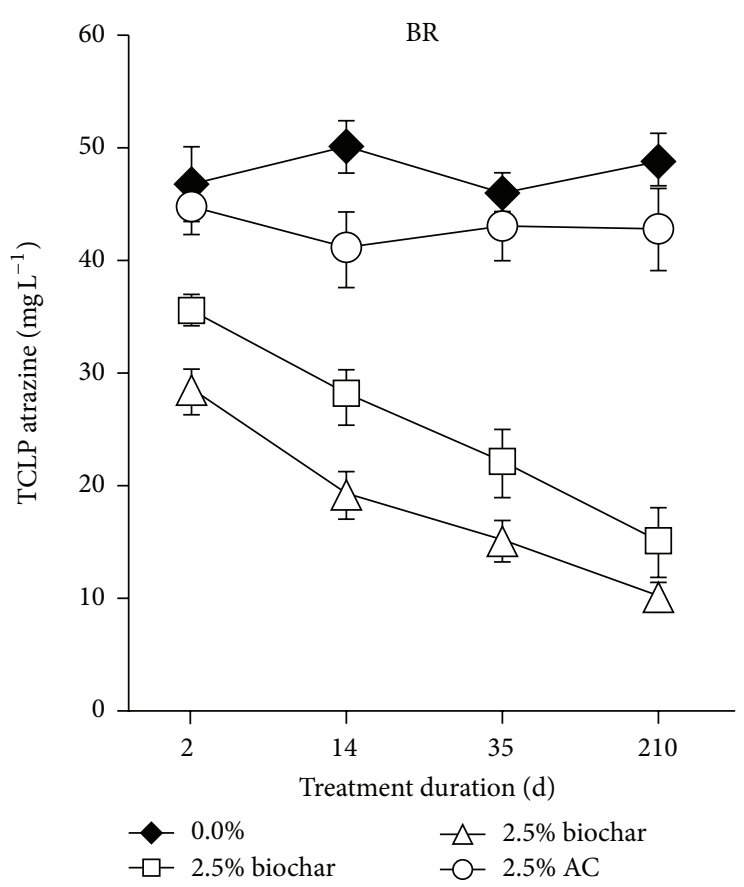

(d)

FIGURE 3: $\mathrm{Pb}$ concentration in the $\mathrm{CaCl}_{2}$ and TCLP extract obtained from soils treated with different doses of biochar.

treatment resources from the perspectives of both resource conservation and environmental remediation [84].

Nanotechnology is a field of applied science, focused on the design, synthesis, characterization, and application of materials and devices on the nanoscale. Nanotechnology holds out the promise of massive progresses in manufacturing technologies, electronics, telecommunications, health, and even environmental remediation [24]. It involves the manufacture and application of a miscellaneous variety of NMs, which include structures and devices that range in size from 1 to $100 \mathrm{~nm}$ and exhibit distinctive characteristics not contained by bulk-sized materials [37]. Various types of nanomaterials exist, such as carbon-based NMs [85], $\mathrm{TiO}_{2} \mathrm{NMs}$ [86], and iron oxide NMs [66]. 


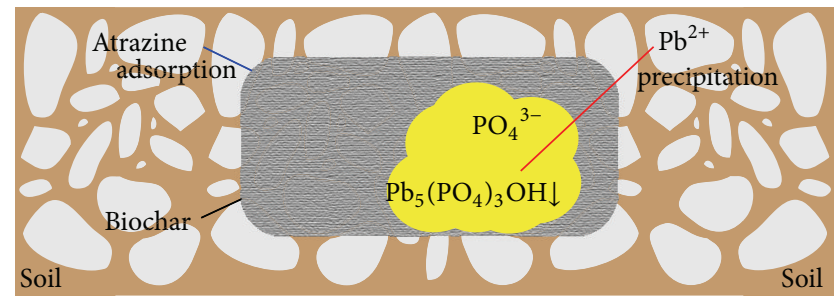

FIGURE 4: Mechanism for $\mathrm{Pb}(\mathrm{II})$ precipitation and atrazine adsorption on biochar.

Iron oxides are present in different forms in the universe. Magnetite $\left(\mathrm{Fe}_{3} \mathrm{O}_{4}\right)$, maghemite $\left(\gamma\right.$ - $\left.\mathrm{Fe}_{2} \mathrm{O}_{3}\right)$, and hematite $(\alpha$ $\mathrm{Fe}_{2} \mathrm{O}_{3}$ ) are well known. In recent years, the production and utilization of iron oxide NMs with innovative properties and functions have been extensively studied, because of their size in nanorange, high surface area to volume ratios, and superparamagnetism [87]. Predominantly, the easy manufacturing, coating, or amendment and the ability to control or manipulate matter on anatomic scale could offer incomparable flexibility for utilization [88]. Furthermore, iron oxide NMs with low harmfulness, chemical inertness, and biocompatibility represent a remarkable potential coupling with biotechnology because it has great potential to reduce immobilization of microorganisms and in turn provide greater bioavailability of contaminants. In addition, stabilization of nanoparticles on cell surface can improve its stability, reusability, mechanical strength, and the ease of treatment [89].

3.2.1. Simultaneous Removal by Bionanocatalysis. A new biologically inspired method to produce a nanoparticulate catalyst involves the precipitation of transition metals such as palladium, gold, and iron on bacterial surface, resulting in the formation of bionano-Met [29] which have high potential to remove organic and inorganic contaminants from soil and water [90]. Two gram negative model organisms sulfate-reducing bacterium Desulfovibrio desulfuricans [91] and metal-respiring bacterium Shewanella oneidensis [92] have been primarily used to reduce $\mathrm{Pd}(\mathrm{II})$ and subsequently induce precipitation of $\operatorname{Pd}(0)$ nanoparticles on bacteria and formed the bio- $\mathrm{Pd}(0)$ nanoparticles. Ashraf et al. produced a bio- $\operatorname{Pd}(0)$ nanocatalyst which successfully reduced the hexavalent chromium (VI) [93].

Recently, Johnson et al. has prepared the bio- $\mathrm{Pd}(0)$ nanomaterial by precipitating reduced $\mathrm{Pd}(0)$ on $C$. pasteurianum (Figure 6) [29]. Bio-Pd(0) NMs efficiently reduced two azo dyes methyl orange (MO) and Evan's blue (EB). Ten ppm of nano-Pd degraded MO almost 100\% in 7 minutes (Figure 7) whereas 5 ppm of bio- $\mathrm{Pd}(0)$ decolorized EB almost $100 \%$ in 7 minutes (Figure 8).

In another study, it was found that only $50 \mathrm{mg} \mathrm{L}^{-}$of bio$\mathrm{Pd}(0)$ reduced seven highly toxic PCBs up to $27 \%$ of their initial level. Whereas, $500 \mathrm{mg} \mathrm{L}^{-}$of commercial $\mathrm{Pd}(0)$ powder reduced the same concentration of PCBs [92]. Isolated bacterial strains Pseudomonas aeruginosa and zerovalent iron $\left(\mathrm{Fe}^{0}\right)$ accelerated heavy metal reduction capacity for $\mathrm{Cr}(\mathrm{VI})$ and cadmium, $72.97 \%$ and $87.63 \%$, respectively [94].

Pang et al. developed a synergistic system by immobilizing the Saccharomyces cerevisiae on the surface of chitosancoated magnetic nanoparticles (SICCM) for adsorption of $\mathrm{Cu}$ (II) from aqueous solution (Figures 9(a), 9(b), and 9(c)) [95]. After immobilization, magnetic adsorbent was pure $\mathrm{Fe}_{3} \mathrm{O}_{4}$ and it was without conglobation. Initial $\mathrm{pH}$ level of $\mathrm{Cu}$ (II) solution, concentration of $\mathrm{Cu}$ (II) solution, and application time were factors which influenced the final \% removal of $\mathrm{Cu}(\mathrm{II})$. Highest adsorption potential was obtained at $\mathrm{pH} 4.5$ (Figure 10). When initial dose of $\mathrm{Cu}(\mathrm{II})$ was $60 \mathrm{mg} \mathrm{L}^{-}$, then highest adsorption capacity obtained was $96.8 \%$ and this \% removal efficiency increased as initial dose of $\mathrm{Cu}(\mathrm{II})$ increased (Figure 11). Equilibrium was obtained in 1 hour. The highest adsorption capacity for $\mathrm{Cu}(\mathrm{II})$ was assessed to be $144.9 \mathrm{mg} \mathrm{g}^{-}$. The tremendous feature of CCM for adsorption of heavy metals can be attributed to (1) high hydrophilicity due to large number of hydroxyl groups of glucose units, (2) presence of a large number of functional groups (acetamido, primary amino, so that it can absorb heavy metal ions in wastewater treatment and/or hydroxyl groups), (3) high tendency of these functional groups to react, and (4) flexible structure of the polymer chain.

Polyvinyl alcohol (PVA), sodium alginate, and multiwalled carbon nanotubes (MCNTs) were used by Pang et al. to immobilize a bacterial strain Pseudomonas aeruginosa. Prepared beads were kept at freezing temperature to improve its mechanical strength [96]. At $80 \mathrm{mg} \mathrm{L}^{-} \mathrm{Cr}(\mathrm{VI})$ concentration, $50 \% \mathrm{Cr}(\mathrm{VI})$ of its initial concentration was reduced in 84 hours. However, bacterial cells which were not immobilized became deactivate at this concentration. The beads were applied nine times for removal at $50 \mathrm{mg} \mathrm{L}^{-}$ $\mathrm{Cr}(\mathrm{VI})$ concentration. On first application, 90\% removal was achieved, while in the end $65 \%$ removal efficiency was achieved (Table 2).

3.2.2. Reduction of Heavy Metals by Engineered Nanoparticles. Among natural reductant of $\mathrm{Cr}(\mathrm{VI})$, zerovalent iron is an alternative in the remediation of polluted sites, converting $\mathrm{Cr}(\mathrm{VI})$ to essentially nontoxic $\mathrm{Cr}$ (III). At $0.4 \mathrm{~g} \mathrm{~L}^{-}$concentration of zerovalent iron, $100 \%$ of $\mathrm{Cr}(\mathrm{VI})\left(20 \mathrm{mg} \mathrm{L}^{-}\right)$was reduced. Reduction potential of $\mathrm{Cr}(\mathrm{VI})$ suppressed markedly as initial $\mathrm{pH}$ increased. It was concluded that in each case $\mathrm{Cr}(\mathrm{OH})_{3}$ should be the final product of $\mathrm{Cr}(\mathrm{VI})$ (1). In this way, iron nanoparticles are best option for the remediation of heavy metals in groundwater and soil [97]. Consider

$$
\begin{gathered}
\mathrm{CrO}_{4}{ }^{2-}+\mathrm{Fe}^{0}+8 \mathrm{H}^{+} \longrightarrow \mathrm{Fe}^{3+}+\mathrm{Cr}^{3+}+4 \mathrm{H}_{2} \mathrm{O} \\
(1-x) \mathrm{Fe}^{3+}+(x) \mathrm{Cr}^{3+}+2 \mathrm{H}_{2} \mathrm{O} \\
\longrightarrow \mathrm{Fe}_{(1-x)} \mathrm{Cr}_{x} \mathrm{OOH}_{(\mathrm{S})}+3 \mathrm{H}^{+}
\end{gathered}
$$

High removal efficiency of heavy metals and organic contaminants can be achieved by making amendments to 


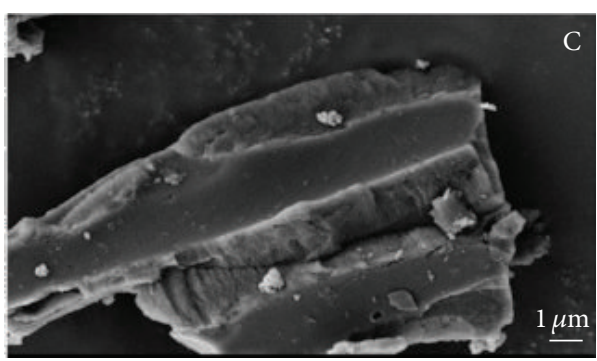

(a)

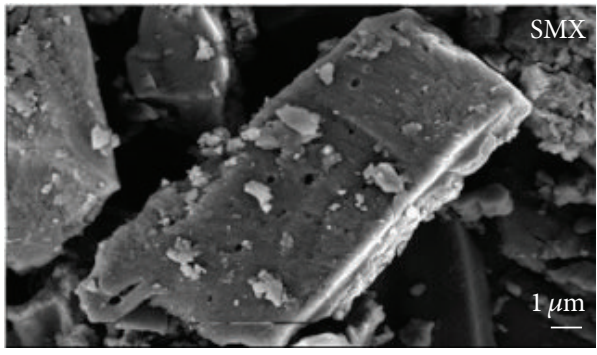

(c)

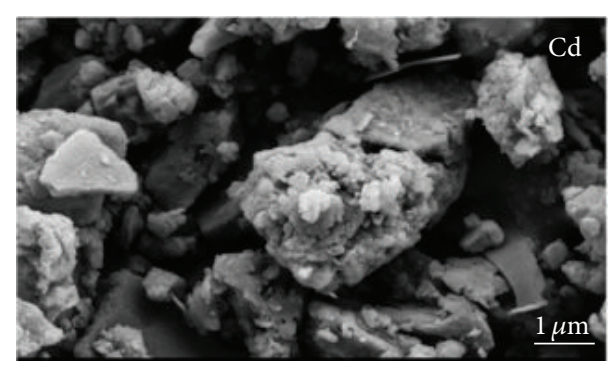

(b)

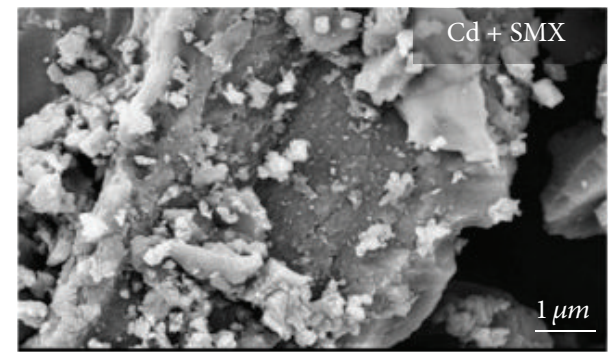

(d)

FIGURE 5: ESEM images of rice straw biochar before and after treatment with solutions of Cd and SMX.

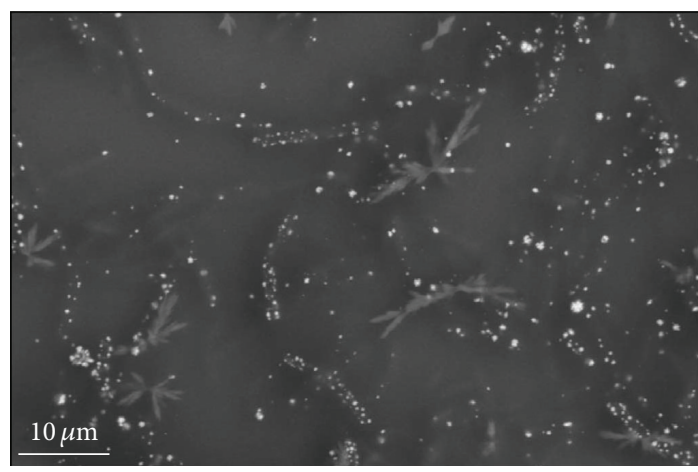

FIGURE 6: SEM image of bio-Pd(0) nanoparticles.

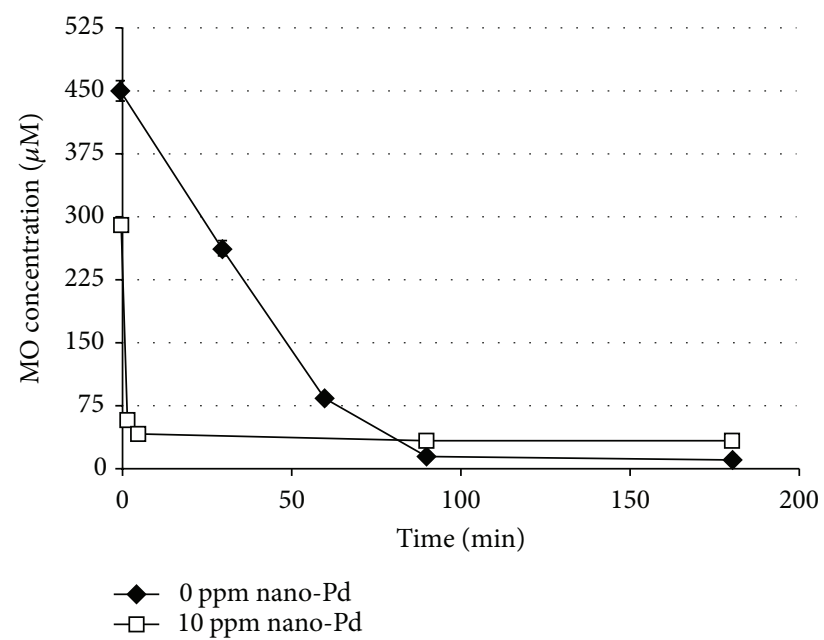

FIGURE 7: Concentration of methyl orange at different levels of bio$\operatorname{Pd}(0)$ nanoparticles.

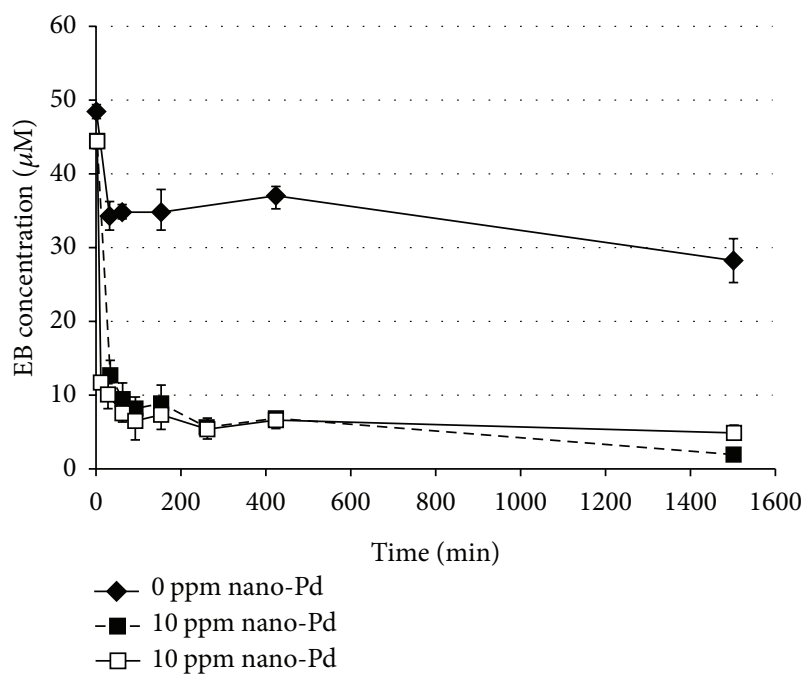

Figure 8: Concentration of Evan's blue at different levels of bio$\operatorname{Pd}(0)$ nanoparticles.

NMs. For example, a novel magnetic nanosorbent (MNP$\mathrm{NH}_{2}$ ) has been produced by the covalent binding of 1,6hexadiamine on the surface of $\mathrm{Fe}_{3} \mathrm{O}_{4}$ nanoparticles for the removal of $\mathrm{Cu}^{2+}$ ions from aqueous solution [98]. The chemisorptions occurred between $\mathrm{Cu}^{2+}$ and $\mathrm{NH}_{2}$ groups on the surface of $\mathrm{MNP}-\mathrm{NH}_{2}$, as shown in

$$
\mathrm{MNP}-\mathrm{NH}_{2}+\mathrm{Cu}^{+2} \longrightarrow \mathrm{MNP}-\mathrm{NH}_{2} \mathrm{Cu}^{+2} \text {. }
$$

In addition, the prepared nanosorbents had good reusability and stability, and the adsorption capacity of $\mathrm{MNP}-\mathrm{NH}_{2}$ was kept constant (about $25 \mathrm{mg} \mathrm{g}^{-}$). 


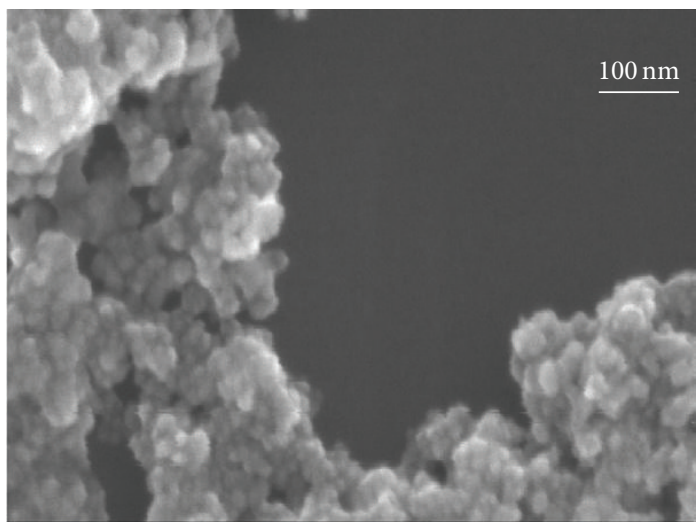

(a)

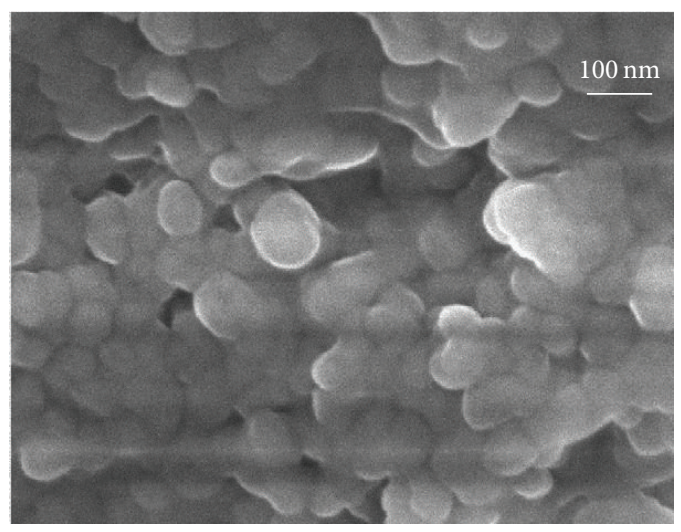

(b)

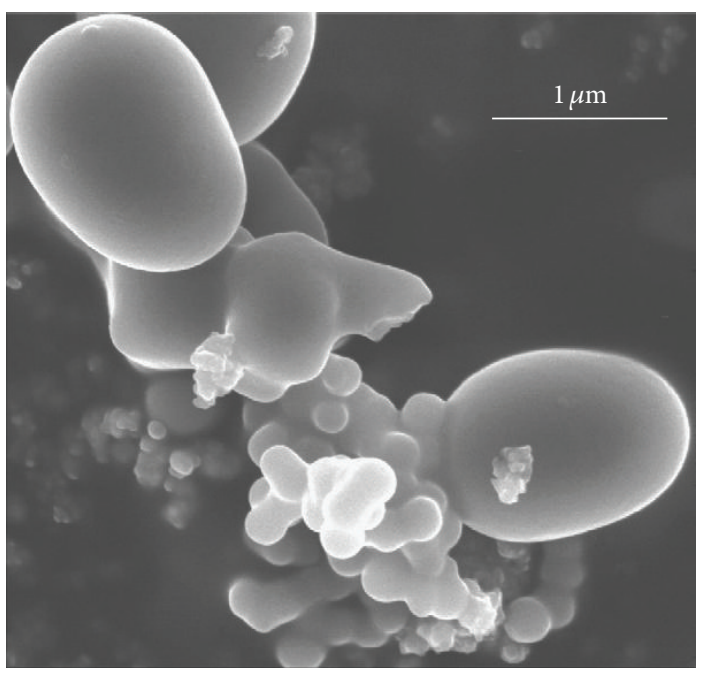

(c)

Figure 9: (a) Transmission electron micrograph of $\mathrm{Fe}_{3} \mathrm{O}_{4}$ magnetic nanoparticles and (b) chitosan-coated magnetic nanoparticles. (c) Immobilized $S$. cerevisiae on the surface of chitosan-coated magnetic nanoparticles.

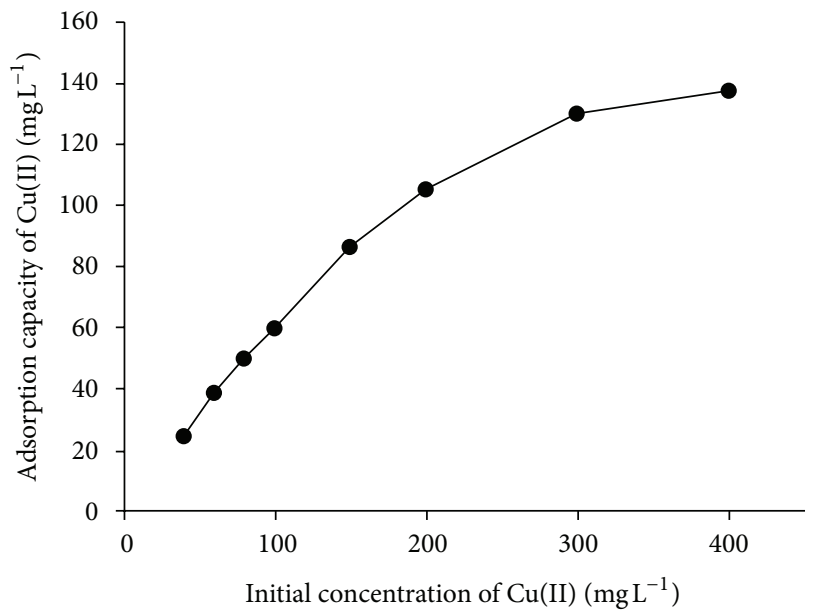

Figure 10: Adsorption capacities of $\mathrm{Cu}(\mathrm{II}) \mathrm{mg} \mathrm{L}^{-}$by S. cerevisiae immobilized on chitosan-coated magnetic nanoparticles at different initial concentrations of $\mathrm{Cu}(\mathrm{II}) \mathrm{mg} \mathrm{L}^{-}$.
Various forms of $\mathrm{Fe}^{0}$ were compared in the same conditions. The potential to degrade $\mathrm{Cr}(\mathrm{VI})$ was in the following order: starch-stabilized $\mathrm{Fe}^{0}$ nanoparticles $>\mathrm{Fe}^{0}$ nanoparticles $>\mathrm{Fe}^{0}$ powder $>\mathrm{Fe}^{0}$ filings (Figure 12). Figure 13 shows the ESEM images of the alone $\mathrm{Fe}^{0}$ nanoparticles (a) and starch stabilizer $\mathrm{Fe}^{0}$ nanoparticles (b). Much larger dendritic flocs have been formed without starch whereas discrete $\mathrm{Fe}^{0}$ nanoscale particles have been formed in the presence of starch (splinter-shaped crystalloid). The presence of starch effectively prevents accumulation of the iron particles and thus keeps high surface area and great reactivity [97].

Mesoporous gamma- $\mathrm{Fe}_{2} \mathrm{O}_{3}$ nanoparticles possess superparamagnetic properties. It has comparatively great potential to remove $\mathrm{Cr}(\mathrm{VI})$ ions from the aqueous solution to that of pristine CMK-3 carbon. It was found that mesoporous gamma- $\mathrm{Fe}_{2} \mathrm{O}_{3}$ nanoparticles $(10 \mathrm{~nm})$ had large adsorption capacity as compared to nonporous gamma- $\mathrm{Fe}_{2} \mathrm{O}_{3}$ nanoparticles under same experimental conditions and degradation 


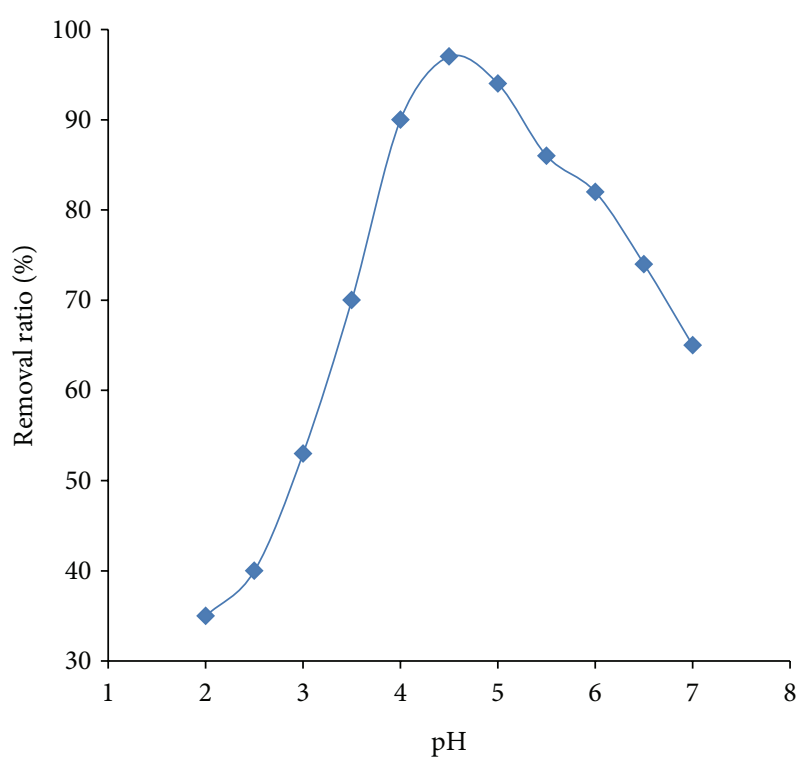

Figure 11: Removal ratio (\%) of Cu(II) by S. cerevisiae immobilized on chitosan-coated magnetic nanoparticles at different $\mathrm{pH}$ levels.

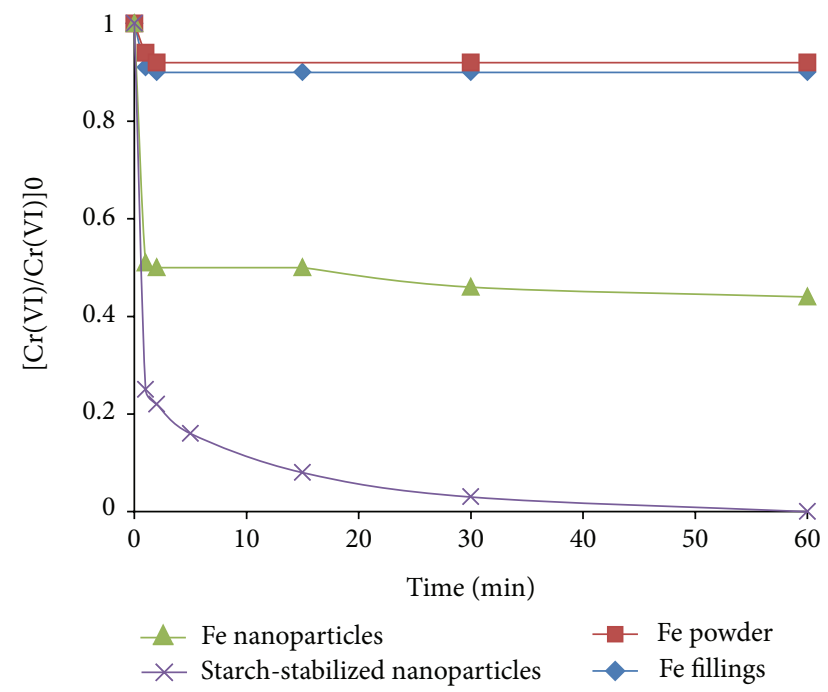

FIGURE 12: Concentration of $\mathrm{Cr}(\mathrm{VI})$ treated with different forms of $\mathrm{Fe}^{0}$ nanoparticles.

strength of mesoporous gamma- $\mathrm{Fe}_{2} \mathrm{O}_{3}$ nanoparticles for $\mathrm{Cr}(\mathrm{VI})$ increased as $\mathrm{pH}$ level of solution decreased [99].

Montmorillonite-supported magnetite nanoparticles were developed by coprecipitation and hydrosol method. The average sizes of the magnetite nanoparticles without and with montmorillonite support are around 25 and $15 \mathrm{~nm}$, respectively. Adsorption potential of montmorillonite-supported magnetite nanoparticles was significantly higher per unit mass of magnetite $\left(15.3 \mathrm{mg} \mathrm{g}^{-}\right)$than that of unsupported magnetite $\left(10.6 \mathrm{mg} \mathrm{g}^{-}\right)$for heavy metal [100]. Similarly, bentonite-supported nanoscale zerovalent iron (B-nZVI) was prepared using liquid-phase reduction. Electroplating wastewater was treated with B-nZVI which exhibited higher potential to remove $\mathrm{Cr}, \mathrm{Pb}$, and $\mathrm{Cu}>90 \%$ [20].
Nanoscale zerovalent iron- (nZVI-) multiwalled carbon nanotube (MWCNT) nanocomposites were applied to reduce $\mathrm{Cr}(\mathrm{VI})$ from wastewater. These were synthesized by embedding nZVI particles onto MWCNTs by in situ reduction of ferrous sulfate. The nZVI-MWCNT nanocomposites revealed around 36\% higher reduction potential for $\mathrm{Cr}(\mathrm{VI})$ removal than that of bare nZVI or nZVI-activated carbon composites. Rate of removal of $\mathrm{Cr}(\mathrm{VI})$ increased at low $\mathrm{pH}$ and initial $\mathrm{Cr}(\mathrm{VI})$ concentration. Anions, such as $\left(\mathrm{SO}_{4}\right)^{2-}$, $\mathrm{NO}_{3}{ }^{-}$, and $\mathrm{HCO}_{3}{ }^{-}$, exerted negative impacts on the removal of $\mathrm{Cr}(\mathrm{VI})$, while the influence of $\mathrm{PO}_{4}{ }^{3-}$ and $\mathrm{SiO}_{3}{ }^{2-}$ was not significant [101].

Li et al. developed silica fume-supported $\mathrm{Fe}(0)$ nanoparticles $(\mathrm{SF}-\mathrm{Fe}(0))$ that were prepared using commercial silica fume as a support [102]. The feasibility of using this SF$\mathrm{Fe}(0)$ immobilized the $\mathrm{Cr}(\mathrm{VI})$ by adsorption on its surface following the reduction of $\mathrm{Cr}(\mathrm{VI})$ to $\mathrm{Cr}(\mathrm{III})$. The rate of reduction of $\mathrm{Cr}(\mathrm{VI})$ could be explained by pseudofirst-order reaction kinetics.

Surface engineered magnetic nanoparticles $\mathrm{Fe}_{3} \mathrm{O}_{4}$ were produced by facile soft-chemical approaches. Nanoadsorbents were functionalized with carboxyl (succinic acid), amine (ethylenediamine), and thiol (2,3-dimercaptosuccinic acid). It has been suggested that nanoparticles formed in carboxyl, thiol, and amine functionalized $\mathrm{Fe}_{3} \mathrm{O}_{4}$ have average sizes of about 10,6 , and $\sim 40 \mathrm{~nm}$, respectively. Rate of removal for heavy metals $\left(\mathrm{Cr}^{3+}\right),\left(\mathrm{Co}^{2+}\right),\left(\mathrm{Ni}^{2+}\right),\left(\mathrm{Cu}^{2+}\right),\left(\mathrm{Cd}^{2+}\right)$, $\left(\mathrm{Pb}^{2+}\right)$, and $\left(\mathrm{As}^{3+}\right)$ and bacterial pathogens (Escherichia coli) from water was highly efficient. Mechanism of removal of heavy metals involves the formation of chelate complexes or ion exchange process or electrostatic interaction depending upon the surface functionality $\left(\mathrm{COOH}, \mathrm{NH}_{2}\right.$, or $\left.\mathrm{SH}\right)$ of magnetic nanoadsorbents [94].

It was explored by Wei et al. that magnetically iron-nickel oxide has great power for selective adsorption of $\mathrm{Cr}(\mathrm{VI})$ from the wastewater having $\mathrm{Cr}(\mathrm{VI})-\mathrm{Ni}$ (II) [103]. The maximum adsorption capacity of $\mathrm{Cr}(\mathrm{VI})$ is about $30 \mathrm{mg} \mathrm{g}^{-}$at $\mathrm{pH} 5.00$ \pm 0.02 , and it was negatively correlated with total dissolved substance (TDS). Magnetic iron oxide nanoparticles were synthesized by a coprecipitation method followed by modification with 3-aminopropyl triethoxysilane (APTES) and acryloyl chloride (AC) subsequently. Then, the surface of modified nanoparticles was amended by graft polymerization with acrylic acid. The grafted magnetite nanoparticles exhibited great potential to capture heavy metal cations such as $\mathrm{Cd}^{2+}, \mathrm{Pb}^{2}, \mathrm{Ni}^{2+}$, and $\mathrm{Cu}^{2+}$. Their size was in range of 10 to $23 \mathrm{~nm}$. Adsorption capacity was reported to be $57.1 \mathrm{emu} \mathrm{g}^{-}$ [104]. Nanoscale $\delta-\mathrm{MnO}_{2}$ particles were embedded on the surfaces of GNS. It was found that $\mathrm{GNS} / \mathrm{MnO}_{2}$ have efficient capturing potential for $\mathrm{Ni}$ (II) from solution and it is $46.6 \mathrm{mg}$ $\mathrm{g}^{-}$at room temperature, which is 1.5 and 15 times higher than those of pure $\delta-\mathrm{MnO}_{2}$ and GNS, respectively [105].

Wastewaters often contain organics and heavy metals. Several experiments have been conducted to remove organic contaminants and heavy metals simultaneously using ironbased NMs stabilized on a surface. Currently, Long et al. 


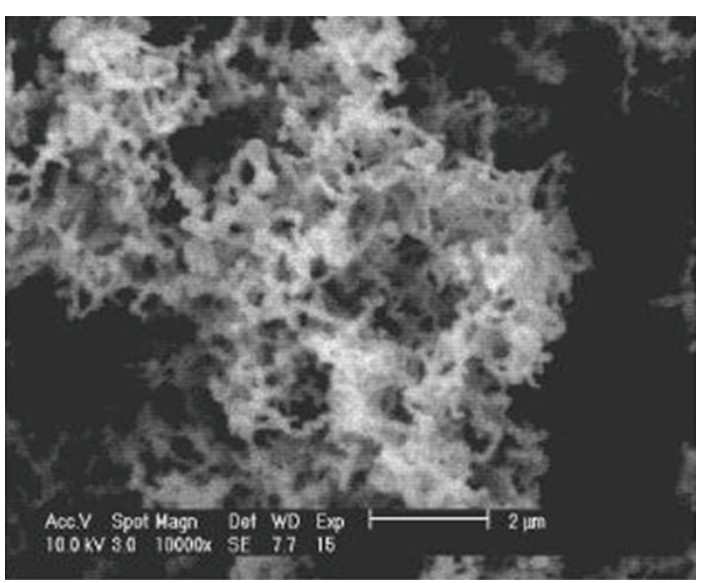

(a)

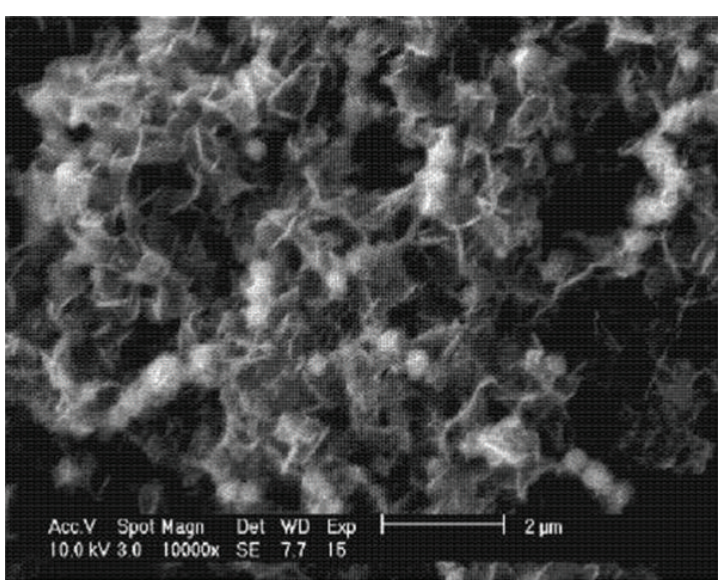

(b)

FIGURE 13: ESEM images of (a) alone $\mathrm{Fe}^{0}$ nanoparticles and (b) starch stabilizer $\mathrm{Fe}^{0}$ nanoparticles.

TABLE 2: Bio-nanocatalysts to remove heavy metals and organic contaminants.

\begin{tabular}{|c|c|c|c|c|c|c|c|c|c|}
\hline \multirow[t]{2}{*}{ Bionanocatalysts } & \multirow{2}{*}{$\begin{array}{l}\text { Organic } \\
\text { compounds }\end{array}$} & \multirow{2}{*}{$\begin{array}{l}\text { Heavy } \\
\text { metals }\end{array}$} & \multirow{2}{*}{$\begin{array}{l}\text { Initial } \\
\text { concentration of } \\
\text { bionanocatalysts } \\
\left(\mathrm{ppm} / \mathrm{mg} \mathrm{L}^{-}\right)\end{array}$} & \multirow{2}{*}{$\begin{array}{l}\text { Initial } \\
\text { concentration of } \\
\text { heavy metals } \\
\left(\mathrm{mgl}^{-}\right)\end{array}$} & \multicolumn{2}{|c|}{$\begin{array}{c}\text { Maximum reduction } \\
(\%)\end{array}$} & \multicolumn{2}{|c|}{$\begin{array}{l}\text { Time for maximum } \\
\text { reduction }(\mathrm{min} / \mathrm{h})\end{array}$} & \multirow[t]{2}{*}{ References } \\
\hline & & & & & O.C. & $\begin{array}{l}\text { Heavy } \\
\text { metals }\end{array}$ & O.C. & $\begin{array}{l}\text { Heavy } \\
\text { metals }\end{array}$ & \\
\hline $\begin{array}{l}{[\mathrm{Bio}-\mathrm{Pd}(0) \mathrm{NMs}]} \\
\mathrm{Pd}(0) \text { precipitated } \\
\text { on C. pasteurianum }\end{array}$ & $\begin{array}{c}\text { Methyl } \\
\text { orange (MO) }\end{array}$ & - & $10 \mathrm{ppm}$ & - & $100 \%$ & - & $7 \mathrm{~min}$ & - & [29] \\
\hline $\begin{array}{l}\mathrm{Pd}(0) \text { precipitated } \\
\text { on C. pasteurianum }\end{array}$ & $\begin{array}{l}\text { Evan's blue } \\
\text { (EB) }\end{array}$ & - & $5 \mathrm{ppm}$ & - & $100 \%$ & - & $7 \mathrm{~min}$ & - & [29] \\
\hline Bio-Pd(0) NMs & PCBs & - & $50 \mathrm{mg} \mathrm{L}^{-}$ & - & $27 \%$ & - & - & - & {$[92]$} \\
\hline $\begin{array}{l}\text { P. aeruginosa } \\
\text { immobilized }\left(\mathrm{Fe}^{0}\right)\end{array}$ & - & $\mathrm{Cr}(\mathrm{VI})$ & - & - & - & $72.97 \%$ & - & - & {$[95]$} \\
\hline $\begin{array}{l}\text { P. aeruginosa } \\
\text { immobilized }\left(\mathrm{Fe}^{0}\right)\end{array}$ & - & $\mathrm{Cd}(\mathrm{II})$ & - & - & - & $87.63 \%$ & - & - & {$[92]$} \\
\hline $\begin{array}{l}\text { S. cerevisiae } \\
\text { immobilized on } \\
\text { chitosan-coated } \\
\text { magnetic } \\
\text { nanoparticles }\end{array}$ & - & $\mathrm{Cu}(\mathrm{II})$ & - & $60 \mathrm{mg} \mathrm{L}^{-}$ & - & $96.8 \%$ & - & $1 \mathrm{~h}$ & {$[95]$} \\
\hline $\begin{array}{l}\text { P. aerugi- } \\
\text { nosaimmobilized } \\
\text { on multiwalled } \\
\text { carbon nanotubes }\end{array}$ & - & $\mathrm{Cr}(\mathrm{VI})$ & - & $80 \mathrm{mg} \mathrm{L}^{-}$ & - & $50 \%$ & - & $84 \mathrm{~h}$ & [95] \\
\hline
\end{tabular}

synthesized chitosan-stabilized bimetallic Fe/Ni nanoparticles (CS-Fe/Ni) which efficiently reduced the amoxicillin by $68.9 \%$ and absorbed Cd(II) by $81.3 \%$ from a cocontaminated water [83], whereas separate reduction and adsorption rate for amoxicillin and Cd(II) were $93.0 \%$ and $90.9 \%$, respectively, within 60 minutes. In this way, this remediation technique involves the reduction chemically and adsorption (Table 3).

3.2.3. Simultaneous Removal by Nanophotocatalysis. In this synergistic system, N-F-codoped $\mathrm{TiO}_{2}$ was used as a photocatalyst under visible light with enhanced photo efficiency to reduce $\mathrm{Cr}(\mathrm{VI})$ and benzoic acid (BA). Ratio of $\mathrm{Cr} / \mathrm{BA}$ and concentration of N-F-codoped $\mathrm{TiO}_{2}$ and $\mathrm{pH}$ were the selected variables, which effected significantly the removal of $\mathrm{Cr}(\mathrm{VI})$ and BA. Maximum degradation of $\mathrm{Cr}(\mathrm{VI})$ and BA was achieved at $\mathrm{pH}=4$, ratio $\mathrm{Cr} / \mathrm{BA}=5$, and $\mathrm{N}$-F-codoped $\mathrm{TiO}_{2}$ $=600 \mathrm{mg} \mathrm{L}^{-}$. Reduction of $\mathrm{Cr}(\mathrm{VI})$ was suppressed as $\mathrm{pH}$ level increased, because of the anionic-type adsorption on $\mathrm{TiO}_{2}$ and its acid-catalyzed photocatalytic reduction and the same trend was followed by BA. Figures 14 and 15 represent that, in binary system, no degradation was observed in the presence of only N-F-codoped $\mathrm{TiO}_{2}$ after incubation for $240 \mathrm{~min}$, whereas, in case of direct photolysis only, reduction of $\mathrm{Cr}(\mathrm{VI})$ and BA occurred at very slow rate. On the other hand, in single system, photocatalytic treatment completely reduced 


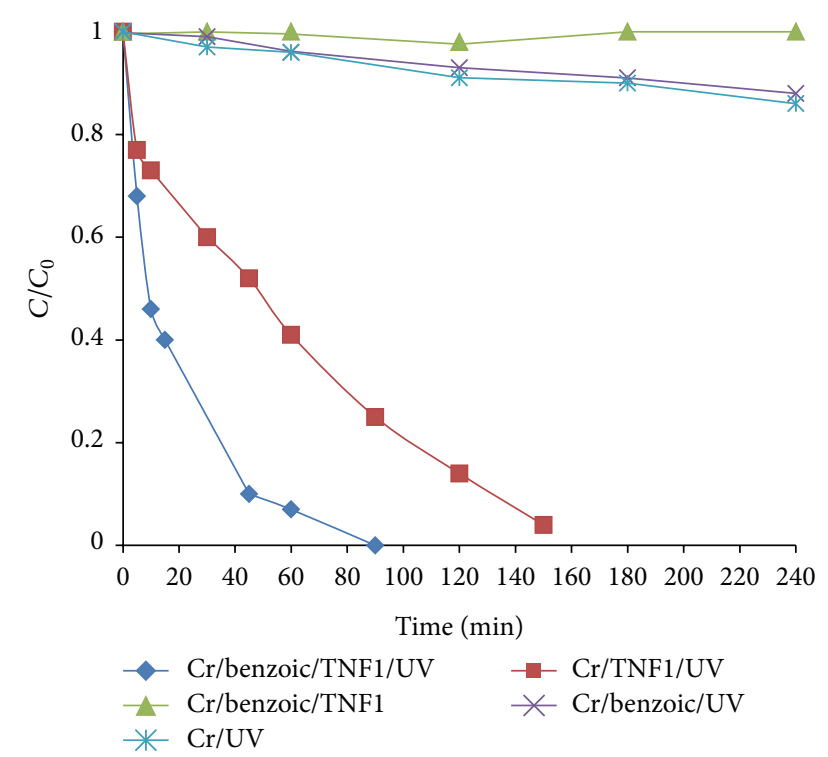

Figure 14: Photocatalytic reduction of $\mathrm{Cr}(\mathrm{VI})$ in single and binary system.

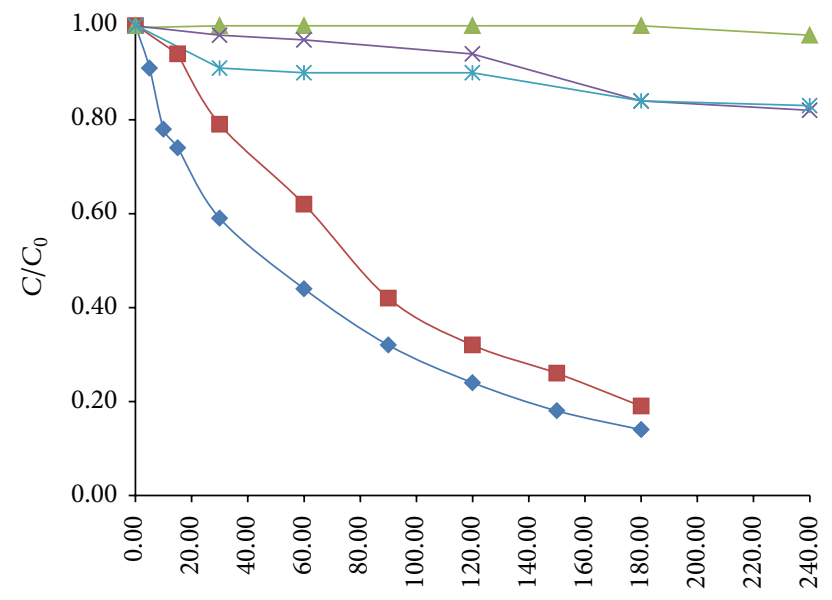

Time (min)

$\begin{array}{ll}\leftarrow \text { Cr/benzoic/TNF1/UV } & * \text { Benzoic/UV1 } \\ * \mathrm{Cr} / \text { benzoic/UV } & -\mathrm{Cr} / \text { benzoic/TNF1 } \\ - \text { Benzoic/TNF1/UV } & \end{array}$

FIGURE 15: Photocatalytic reduction of benzoic acid (BA) in single and binary system.

$\mathrm{Cr}(\mathrm{VI})$ and BA after 150 and $240 \mathrm{~min}$, respectively, while in binary system photocatalytic reduction of $\mathrm{Cr}(\mathrm{VI})$ and BA significantly boosted the oxidation/reduction of substrate and complete reduction of $\mathrm{Cr}(\mathrm{VI})$ maximum reduction of $\mathrm{BA}$ was achieved after incubation for 90 and $180 \mathrm{~min}$, respectively. Mechanism for enhanced degradation includes the coupled oxidation of the BA that consumes photogenerated holes and/or ${ }^{\circ} \mathrm{OH}$ radicals efficiently, blocking the electron-hole recombination and, thus, increasing the total efficiency [38].

Moreover, the efficiency of $\left(\mathrm{EDAS} / \mathrm{TiO}_{2}-\mathrm{Au}\right)$ (nps) nanocomposite materials for photocatalytic oxidation and reduction was assessed by applying them on $\mathrm{Cr}(\mathrm{VI})$ and methylene blue $(\mathrm{MB})$ dye under irradiation. Deposition of $\mathrm{Au}$ nanoparticles on $\mathrm{TiO}_{2}$ nanoparticles and then its spreading over silicate sol-gel film $\left(\mathrm{EDAS} /\left(\mathrm{TiO}_{2}-\mathrm{Au}\right)\right)$ (nps) enhanced the photocatalytic reduction for $\mathrm{Cr}(\mathrm{VI})$ and oxidation of MB. Mechanism involves the most active interfacial electron transfer from the conduction band of the $\mathrm{TiO}_{2}$ to $\mathrm{Au}$ (nps) by minimizing the charge recombination process when compared to the $\mathrm{TiO}_{2}$ and $\left(\mathrm{TiO}_{2}-\mathrm{Au}\right)$ (nps) in the absence of EDAS [106].

Similarly, Doong et al. prepared metal-deposited Degussa $\mathrm{P} 25 \mathrm{TiO}_{2}$ nanoparticles. Copper and silver ions were embedded on $\mathrm{TiO}_{2}$ to accelerate photocatalytic degradation of methylene blue (MB) [107]. It was found that presence of formate stimulated the photocatalytic reduction of heavy metal ions by dropping its oxidation number and resulting in fast rate of photoreduction. In case of Degussa $\mathrm{P} 25 \mathrm{TiO}_{2}$ nanoparticles, rate constant $(k$ (obs)) for $\mathrm{MB}$ photodegradation was found to be $3.943 .94 \times 10^{-2} \mathrm{~min}^{-}$, whereas rate constant $(k$ (obs) ) increased by 1.4-1.7 times when metaldeposited Degussa P25 $\mathrm{TiO}_{2}$ nanoparticles were applied. Concentration of heavy metal ions was also a factor which prompted the photodegradation of $\mathrm{MB}$. Therefore, the rate constant reached up to $4.64-7.28 \times 10^{-2} \mathrm{~min}^{-}$for $\mathrm{Ag} / \mathrm{TiO}_{2}$ and to $5.14-7.61 \times 10^{-2} \mathrm{~min}^{-}$for $\mathrm{Cu} / \mathrm{TiO}_{2}$. Furthermore, the electrons released from $\mathrm{TiO}_{2}$ may contribute to reducing heavy metal ions and $\mathrm{MB}$ simultaneously.

Simultaneous degradation of Cr(VI) and di-n-butyl phthalate (DBP) by $\mathrm{UV} / \mathrm{TiO}_{2}$ treatment was carried out by Xu et al. [65]. Concentration of $\mathrm{Cr}(\mathrm{VI})$ and $\mathrm{DBP}$ was significantly reduced and $\mathrm{Cr}(\mathrm{VI})$ exerted positive effect on DBP degradation and vice versa.

Similarly, simultaneous photocatalytic reduction/oxidation of Cr/salicylic acid was reported by Wang and Lo [108]. Both $\mathrm{Cr}(\mathrm{VI})$ and salicylic acid were successively reduced. It was investigated that when photocatalytic reduction of $\mathrm{Cr}(\mathrm{VI})$ was carried out for long time, it resulted in deposition of $\mathrm{Cr}$ (III) on the surface of $\mathrm{TiO}_{2}$ particles, which in turn deactivated the photocatalyst. However, this problem was overcome by oxidation of salicylic acid at the same time.

Peng et al. synthesized the polymer-sensitized $\mathrm{TiO}_{2}$ for efficient reduction of $\mathrm{Cr}(\mathrm{VI})$ and oxidation of phenol simultaneously [109]. Poly(fluorene-co-thiophene) (PFT) showed the ability to reduce $\mathrm{Cr}(\mathrm{VI})$. When PFT was joined with $\mathrm{TiO}_{2}$, not only it increased electron donor efficiency of PFT, but also it started to act as a sensitizer. This catalytic reduction of $\mathrm{Cr}(\mathrm{VI})$ was enhanced by the phenol existence. It was investigated by Tabassum et al. that the ultraviolet- (UVA-) induced photocatalytic application reduced the azo dye acid orange $20(\mathrm{AO} 20)$ and $\mathrm{Cr}(\mathrm{VI})$ simultaneously [110]. The complete reduction was obtained after $120 \mathrm{~min}$ or $240 \mathrm{~min}$ at 500 or $250 \mathrm{mg} \mathrm{l}^{-}$concentration of catalyst UV-induced $\mathrm{TiO}_{2}$ at neutral $\mathrm{pH}$. The synergistic effect of $\mathrm{TiO}_{2}$ under visible light $(\lambda>420 \mathrm{~nm})$ to reduce the azo dye acid orange $7(\mathrm{AO} 7)$ and $\mathrm{Cr}(\mathrm{VI})$, simultaneously, was extraordinary. Presence of metal ions enhanced the degradation rate of AO7. Similarly AO7 participated in increasing reduction rate of $\mathrm{Cr}(\mathrm{VI})$ [111].

A novel metal-semiconductor heterojunction with a tube-in-tube structure was synthesized by Luo et al. [112]. 
TABLE 3: Removal of heavy metals by surface stabilized nanomaterials (NMs).

\begin{tabular}{|c|c|c|c|}
\hline Stabilized nanomaterials (NMs) & Heavy metals & $\begin{array}{l}\text { Maximum removal } \\
\% / \mathrm{mg} \mathrm{L}^{-} / \mathrm{emu} \mathrm{g}^{-}\end{array}$ & References \\
\hline Starch stabilizer $\mathrm{Fe}^{0}$ nanoparticles & $\mathrm{Cr}(\mathrm{VI})$ & - & {$[97]$} \\
\hline Mesoporous gamma- $\mathrm{Fe}_{2} \mathrm{O}_{3}$ nanoparticles & $\mathrm{Cr}(\mathrm{VI})$ & - & [99] \\
\hline Montmorillonite-supported magnetite nanoparticles & - & - & {$[100]$} \\
\hline Bentonite-supported nanoscale zerovalent iron (B-nZVI) & $\mathrm{Cr}(\mathrm{VI}), \mathrm{Pb}(\mathrm{II})$, and $\mathrm{Cu}(\mathrm{II})$ & $>90 \%$ & {$[28]$} \\
\hline $\begin{array}{l}\text { Nanoscale zerovalent iron (nZVI)-multiwalled carbon nanotube } \\
\text { (MWCNT) }\end{array}$ & $\mathrm{Cr}(\mathrm{VI})$ & - & {$[101]$} \\
\hline Silica fume supported-Fe $(0)$ nanoparticles $(\mathrm{SF}-\mathrm{Fe}(0))$ & $\mathrm{Cr}(\mathrm{VI})$ & - & {$[102]$} \\
\hline Surface engineered $\mathrm{Fe}_{3} \mathrm{O}_{4}$ & $\mathrm{Cr}(\mathrm{III}), \mathrm{Co}(\mathrm{II})$, and $\mathrm{Ni}(\mathrm{II})$ & - & {$[115]$} \\
\hline Magnetically iron-nickel oxide & $\operatorname{Cr}(\mathrm{VI})$ & $30 \mathrm{mg} \mathrm{L}^{-}$ & {$[103]$} \\
\hline $\begin{array}{l}\text { Iron oxide nanoparticles modified with } \\
\text { 3-aminopropyltriethoxysilane (APTES) and acryloyl chloride (AC) }\end{array}$ & $\begin{array}{l}\mathrm{Ni}(\mathrm{II}), \mathrm{Cr}(\mathrm{VI}), \mathrm{Pb}(\mathrm{II}) \text {, and } \\
\mathrm{Cu}(\mathrm{II})\end{array}$ & $57.1 \mathrm{emu} \mathrm{g}^{-}$ & {$[104]$} \\
\hline Nanoscale $\delta-\mathrm{MnO}_{2}$ embedded on graphene nanosheet & $\mathrm{Ni}(\mathrm{II})$ & $46.6 \mathrm{mg} \mathrm{L}^{-}$ & {$[105]$} \\
\hline Chitosan stabilized bimetallic Fe/Ni nanoparticles (CS-Fe/Ni) & $\mathrm{Cd}(\mathrm{II})$ & $90.9 \%$ & {$[83]$} \\
\hline
\end{tabular}

TABLE 4: Simultaneous removal of heavy metals and organic contaminants by nanophotocatalysts.

\begin{tabular}{|c|c|c|c|c|c|c|c|c|c|}
\hline \multirow[t]{2}{*}{ Synergistic system } & \multirow{2}{*}{$\begin{array}{l}\text { Organic } \\
\text { contaminants }\end{array}$} & \multirow{2}{*}{$\begin{array}{l}\text { Heavy } \\
\text { metals }\end{array}$} & \multicolumn{2}{|c|}{$\begin{array}{c}\text { Maximum removal } \\
(\%)\end{array}$} & \multicolumn{2}{|c|}{ Removal method } & \multicolumn{2}{|c|}{$\begin{array}{l}\text { Time for maximum } \\
\text { removal ( } \mathrm{min})\end{array}$} & \multirow[t]{2}{*}{ References } \\
\hline & & & O.C. & $\begin{array}{l}\text { Heavy } \\
\text { metals }\end{array}$ & O.C. & $\begin{array}{l}\text { Heavy } \\
\text { metals }\end{array}$ & O.C. & $\begin{array}{l}\text { Heavy } \\
\text { metals }\end{array}$ & \\
\hline $\begin{array}{l}\mathrm{N} \text {-F-codoped } \mathrm{TiO}_{2}+ \\
\text { visible light }\end{array}$ & Benzoic acid (BA) & $\mathrm{Cr}(\mathrm{VI})$ & $\begin{array}{l}\text { Around } \\
98 \%\end{array}$ & $100 \%$ & Oxidation & Reduction & $90 \mathrm{~min}$ & $180 \mathrm{~min}$ & {$[38]$} \\
\hline $\begin{array}{l}\mathrm{EDAS} /\left(\mathrm{TiO}_{2}-\mathrm{Au}\right) \mathrm{nps}+ \\
\text { radiations }\end{array}$ & Methylene blue (MB) & $\mathrm{Cr}(\mathrm{VI})$ & - & - & Oxidation & Reduction & - & - & {$[106]$} \\
\hline $\begin{array}{l}\text { Metal-deposited Degussa } \\
\left(\mathrm{P} 25 \mathrm{TiO}_{2}\right) \mathrm{nps}+ \\
\text { radiations }\end{array}$ & Methylene blue (MB) & $\mathrm{Cr}(\mathrm{VI})$ & - & - & Reduction & Reduction & - & - & {$[107]$} \\
\hline $\mathrm{UV} / \mathrm{TiO}_{2}$ & $\begin{array}{l}\text { Di-n-butyl phthalate } \\
\text { (DBP) }\end{array}$ & $\mathrm{Cr}(\mathrm{VI})$ & - & - & - & Reduction & - & - & {$[65]$} \\
\hline $\mathrm{UV} / \mathrm{TiO}_{2}$ & Salicylic acid & $\mathrm{Cr}(\mathrm{VI})$ & - & - & Oxidation & Reduction & - & - & {$[108]$} \\
\hline $\begin{array}{l}\text { Polymer-sensitized } \mathrm{TiO}_{2} \\
\text { + irradiations }\end{array}$ & Phenol & $\mathrm{Cr}(\mathrm{VI})$ & - & - & Oxidation & Reduction & - & - & {$[20]$} \\
\hline UV-induced $\mathrm{TiO}_{2}$ & $\begin{array}{l}\text { Acid orange } 20 \\
(\mathrm{AO} 20)\end{array}$ & $\mathrm{Cr}(\mathrm{VI})$ & $100 \%$ & $100 \%$ & Reduction & Reduction & $120 \mathrm{~min}$ & $120 \mathrm{~min}$ & {$[110]$} \\
\hline $\mathrm{UV} / \mathrm{TiO}_{2}$ & Acid orange 7 (AO7) & $\mathrm{Cr}(\mathrm{VI})$ & $100 \%$ & $100 \%$ & Reduction & Reduction & & & {$[111]$} \\
\hline $\begin{array}{l}\text { Gold nanotubes } \\
\text { embedded in pores of } \\
\mathrm{TiO}_{2} \text { nanotubes }+ \\
\text { radiations }\end{array}$ & Acid orange 7 (AO7) & $\mathrm{Cr}(\mathrm{VI})$ & - & - & Oxidation & Reduction & - & - & {$[112]$} \\
\hline
\end{tabular}

Gold nanotubes comprised of compressed and minute Au particles were deposited in the pores of anodic $\mathrm{TiO}_{2}$ nanotube arrays by a simple pulse electrodeposition technique. An electric potential difference created at the interface of $\mathrm{Au} / \mathrm{TiO}$ heterojunction assisted the availability of photodegraded hole-electron, which in turn enhanced the photocatalytic activity. In binary system, $\mathrm{Cr}(\mathrm{VI})$ and $\mathrm{AO} 7$ reduced very rapidly because of synergistic effect of $\mathrm{Cr}(\mathrm{VI})$-AO7 as well.
3.3. Simultaneous Biodegradation. Biological treatment is usually considered as an effective method and can significantly reduce the quantity of heavy metals in aqueous solutions. Few microbial strains have been isolated to reduce the organic contaminants and adsorption of heavy metals at the same time when cocultured. The most effective fungal strain Phanerochaete chrysosporium has been isolated by Chen et al. which can degrade the 2,4-dichlorophenol and adsorb the cadmium simultaneously in a cocontaminated wastewater [74]. Highest removal (\%) was obtained at $\mathrm{pH} 6.5$ of initial $\mathrm{Cd}(\mathrm{II})$ and 2,4-dichlorophenol doses 


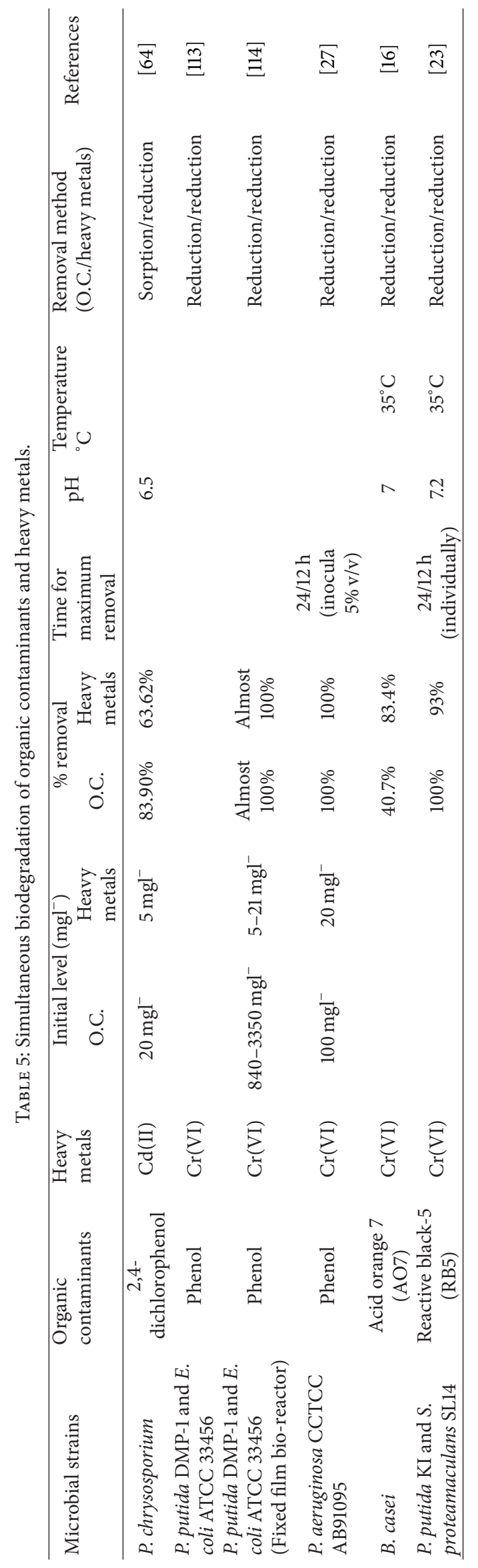


(5 and $20 \mathrm{mg} \mathrm{L}^{-}$), respectively. The reduction and sorption limit for 2,4-dichlorophenol and Cd(II) were $83.90 \%$ and $63.62 \%$, respectively. Furthermore, degradation of 2,4dichlorophenol was indicated by production of lignin peroxidase and manganese peroxidase in surplus amount (i.e., $7.35 \mathrm{U} \mathrm{mL}^{-}$and $8.30 \mathrm{U} \mathrm{mL}^{-}$, resp.). However, production of protein was suppressed as the Cd(II) level increased.

In another experiment, cocontaminated wastewater was treated by combining two bacterial strains Pseudomonas putida DMP-1 and Escherichia coli ATCC 33456. These two bacterial strains rapidly reduced the $\mathrm{Cr}(\mathrm{VI})$ and phenol simultaneously. Reduction of Cr(VI) occurred by metabolism of E. coli. At small population size of E. coli, phenol degradation negatively affected the Cr(VI) degradation. Phenol degradation by $P$. putida was highly sensitive to $\mathrm{Cr}(\mathrm{VI})$ even at its low concentration, whereas phenol exerted inhibitory effect on $\mathrm{Cr}(\mathrm{VI})$ reduction only when phenol concentration was $>9 \mathrm{Mm}$ [113]. Similarly, Nkhalambayausi-Chirwa and Wang explored in an experiment that $\mathrm{Cr}(\mathrm{VI})$ and phenol can be reduced simultaneously by two bacterial strains Escherichia coli ATCC 33456 and Pseudomonas putida DMP1 , respectively, in a fixed-film bioreactor [114]. Almost 100\% reduction of $\mathrm{Cr}(\mathrm{VI})$ and phenol degradation were achieved at initial concentrations (5-21 $\left.\mathrm{mg} \mathrm{L}^{-}\right)$of $\mathrm{Cr}(\mathrm{VI})$ and (840$3350 \mathrm{mg} \mathrm{L}^{-}$) phenol. Metabolites of phenol detected were 1. 2-hydroxymuconic semialdehyde (2HMSA), succinate, and acetate which contributed to increasing TOC by $13-23 \%$ in the treated wastewater.

By the development in biodegradation technology, remediation of $\mathrm{Cr}(\mathrm{VI})$ and organic contaminant simultaneously from wastewater and soil can be achieved by application of single microbial strain. Recently, simultaneous reduction of $\mathrm{Cr}(\mathrm{VI})$ and phenol has been carried out by application of only single strain for both contaminants. Song et al. isolated a fungal strain Pseudomonas aeruginosa CCTCC AB91095 [27]. Phenol served as a source of carbon and in turn energy produced was utilized for $\mathrm{Cr}(\mathrm{VI})$ reduction. Reduction of $\mathrm{Cr}(\mathrm{VI})$ and degradation of phenol was negatively influenced when $\mathrm{Cr}$ (VI) concentration was $>20 \mathrm{mg} \mathrm{L}^{-}$or phenol concentration was $<100 \mathrm{mg} \mathrm{L}^{-}$. Nearly $100 \%$ reduction of $\mathrm{Cr}(\mathrm{VI})$ and phenol occurred after $24 \mathrm{hrs}$. The most effective concentration of inocula was $5 \%(\mathrm{v} / \mathrm{v})$, at which $\mathrm{Cr}(\mathrm{VI})$ and phenol were abruptly suppressed from 20 and 100 to 3.36 and $29.51 \mathrm{mg} \mathrm{L}^{-}$ after $12 \mathrm{~h}$.

Chromate $\mathrm{Cr}(\mathrm{VI})$ and azo dyes are common pollutants which may coexist in some industrial effluents. Therefore, few bacterial strains have been isolated which can reduce $\mathrm{Cr}(\mathrm{VI})$ and decolorize the azo dye simultaneously. A bacterial strain Brevibacterium casei was isolated from sewage sludge of a dyeing factory. Reduction of $\mathrm{Cr}(\mathrm{VI})$ and decolorization of azo dye acid orange 7 (AO7) simultaneously by application of $B$. case $i$ were under nutrient-limiting condition, at $\mathrm{pH} 7$ and $35^{\circ} \mathrm{C}$. Chromate $\mathrm{Cr}(\mathrm{VI})$ and $\mathrm{AO} 7$ reduced by $83.4 \pm 0.6$ and $40.7 \pm 1.7 \%$, respectively. The mechanism of reduction involves that $\mathrm{AO} 7$ reduced by reduction enzyme(s) released from $B$. casei and $\mathrm{AO} 7$ served as an electron donor to reduce
Cr(VI) to $\mathrm{Cr}(\mathrm{III})$. In turn, Cr(III) formed a complex with oxidized AO7 and purple color appeared [16].

Currently, two potential bacterial strains Pseudomonas putida KI and Serratia proteamaculans SL14 were isolated from wastewater and sludge of tannery industry, capable of simultaneous reduction of $\mathrm{Cr}(\mathrm{VI})$ and decolorization of azo dye reactive black-5 (RB5). Maximum reduction of $\mathrm{Cr}(\mathrm{VI})$ and RB5 obtained was $93 \%$ and $100 \%$ after incubation for $24 \mathrm{~h}$ at $\mathrm{pH} 7.2$ and $35^{\circ} \mathrm{C}$. Individually, removal of $\mathrm{Cr}(\mathrm{VI})$ and $\mathrm{RB} 5$ was $100 \%$ after $12 \mathrm{~h}$ incubation (Table 5) [23].

\section{Conclusions}

Azo dyes and $\mathrm{Cr}(\mathrm{VI})$ most often coexist in industrial wastewater. These contaminants enter the environment when released through wastewater and exert many carcinogenic and mutagenic effects on plants, animals, and human health. Therefore, treatment of wastewater and its reuse is a practice related not only to a number of benefits with regard to eater balance and management but also to a number of question marks. Immediate research must be launched towards the direction so as to protect human health and environmental ecosystem. Microorganism (bacteria, fungi) are the potential source to remove these contaminants from soil and wastewater because they are cost effective and environmental friendly and remediate contaminants at faster rate. However, their immobilization can accelerate this treatment more efficiently. In this regard, surface modified nanomaterial and biochar have achieved much attention to remove heavy metals and azo dyes simultaneously. As illustrated in this review, a range of nanomicrobiological techniques have been proposed or are under active development for treatment of polluted soil and wastewater, but many techniques are still at experimental or pilot stage. In conclusion, there is much recent interest in the use of engineered nanomaterial combined with biotechnology as in in situ. In general, the attention in this field is not enough and additional studies should be conducted to increase the knowledge in this field. In addition, health impacts and environmental fate of these nanomaterials need to be addressed before their widespread application.

\section{Conflict of Interests}

The authors declare that there is no conflict of interests regarding the publication of this paper.

\section{Acknowledgment}

This research is supported by High Impact Research MoE Grant UM.C/625/1/HIR/MoE/SC/04 from the Ministry of Education Malaysia. Thanks also for the support by UMRG (RG257-13AFR) and FRGS (FP038-2013B).

\section{References}

[1] A. Stolz, "Basic and applied aspects in the microbial degradation of azo dyes," Applied Microbiology and Biotechnology, vol. 56, no. 1-2, pp. 69-80, 2001. 
[2] A. Pandey, P. Singh, and L. Iyengar, "Bacterial decolorization and degradation of azo dyes," International Biodeterioration and Biodegradation, vol. 59, no. 2, pp. 73-84, 2007.

[3] H. Leub, Industrial Dyes, Chemistry, Properties and Applications, Wiley VCH, Wenheim, Germany, 2003.

[4] A. A. Pourbabaee, F. Malekzadeh, M. N. Sarbolouki, and F. Najafi, "Aerobic decolorization and detoxification of a disperse dye in textile effluent by a new isolate of Bacillus sp," Biotechnology and Bioengineering, vol. 93, no. 4, pp. 631-635, 2006.

[5] C. I. Pearce, J. R. Lloyd, and J. T. Guthrie, "The removal of colour from textile wastewater using whole bacterial cells: a review," Dyes and Pigments, vol. 58, no. 3, pp. 179-196, 2003.

[6] G. Bayramoǧlu, G. Çelik, and M. Y. Arica, "Biosorption of reactive blue 4 dye by native and treated fungus batch and continuous flow system studies," Journal of Hazardous Materials, vol. 137, no. 3, pp. 1689-1697, 2006.

[7] F. O. Topaç, E. Dindar, S. Uçaroğlu, and H. S. Başkaya, "Effect of a sulfonated azo dye and sulfanilic acid on nitrogen transformation processes in soil," Journal of Hazardous Materials, vol. 170, no. 2-3, pp. 1006-1013, 2009.

[8] D. T. Sponza, "Necessity of toxicity assessment in Turkish industrial discharges," Environmental Monitoring and Assessment, vol. 73, no. 1, pp. 41-66, 2002.

[9] S. Asad, M. A. Amoozegar, A. A. Pourbabaee, M. N. Sarbolouki, and S. M. M. Dastgheib, "Decolorization of textile azo dyes by newly isolated halophilic and halotolerant bacteria," Bioresource Technology, vol. 98, no. 11, pp. 2082-2088, 2007.

[10] H. Moawad, W. M. Abd El-Rahim, and M. Khalafallah, "Evaluation of biotoxicity of textile dyes using two bioassays," Journal of Basic Microbiology, vol. 43, no. 3, pp. 218-229, 2003.

[11] E. Bååth, "Thymidine incorporation into macromolecules of bacteria extracted from soil by homogenization-centri- fugation," Soil Biology and Biochemistry, vol. 24, no. 11, pp. 1157-1165, 1992.

[12] J. L. Bader, G. Gonzalez, P. C. Goodell, A. S. Ali, and S. D. Pillai, "Chromium-resistant bacterial populations from a site heavily contaminated with hexavalent chromium," Water, Air, and Soil Pollution, vol. 109, no. 1l-4, pp. 263-276, 1999.

[13] E. Bååth, "Growth rates of bacterial communities in soils at varying $\mathrm{pH}$ : a comparison of the thymidine and leucine incorporation techniques," Microbial Ecology, vol. 36, no. 3, pp. 316-327, 1998.

[14] C. Desai, R. Y. Parikh, T. Vaishnav, Y. S. Shouche, and D. Madamwar, "Tracking the influence of long-term chromium pollution on soil bacterial community structures by comparative analyses of $16 \mathrm{~S}$ rRNA gene phylotypes," Research in Microbiology, vol. 160, no. 1, pp. 1-9, 2009.

[15] G. Dönmez and N. Koçberber, "Isolation of hexavalent chromium resistant bacteria from industrial saline effluents and their ability of bioaccumulation," Enzyme and Microbial Technology, vol. 36, no. 5-6, pp. 700-705, 2005.

[16] E. K. Nyer, Treatment Methods for Inorganic Compounds, Ground Water Treatment Technology, Van Nostrand Reinhold, New York, NY, USA, 3rd edition, 1992.

[17] C. Cervantes and S. Silver, "Plasmid chromate resistance and chromate reduction," Plasmid, vol. 27, no. 1, pp. 65-71, 1992.

[18] X. Weng, S. Lin, Y. Zhong, and Z. Chen, "Chitosan stabilized bimetallic $\mathrm{Fe} / \mathrm{Ni}$ nanoparticles used to remove mixed contaminants-amoxicillin and Cd (II) from aqueous solutions," Bioresource Technology, vol. 102, no. 22, pp. 10733-10736, 2011.
[19] W. Delee, C. O. Neili, and F. R. Hawks, "Anaerobic treatment of textile effluents a review," Journal of Chemical Technology and Biotechnology, vol. 73, no. 4, pp. 323-335, 1998.

[20] L.-N. Shi, X. Zhang, and Z.-L. Chen, "Removal of Chromium (VI) from wastewater using bentonite-supported nanoscale zero-valent iron," Water Research, vol. 45, no. 2, pp. 886-892, 2011.

[21] D. Çetin, S. Dönmez, and G. Dönmez, "The treatment of textile wastewater including chromium(VI) and reactive dye by sulfate-reducing bacterial enrichment," Journal of Environmental Management, vol. 88, no. 1, pp. 76-82, 2008.

[22] A. Khalid, M. Arshad, and D. E. Crowley, "Biodegradation potential of pure and mixed bacterial cultures for removal of 4nitroaniline from textile dye wastewater," Water Research, vol. 43, no. 4, pp. 1110-1116, 2009.

[23] S. Mahmood, A. Khalid, T. Mahmood, M. Arshad, and R. Ahmad, "Potential of newly isolated bacterial strains for simultaneous removal of hexavalent chromium and reactive black5 azo dye from tannery," Journal of Chemical Technology and Biotechnology, vol. 88, no. 8, pp. 1506-1513, 2013.

[24] M. N. Moore, "Do nanoparticles present ecotoxicological risks for the health of the aquatic environment?" Environment International, vol. 32, no. 8, pp. 967-976, 2006.

[25] J. Lehmann and S. Joseph, Biochar for Environmental Management: Science and Technology, Earthscan, London, UK, 2009.

[26] J. Lehmann, "A handful of carbon," Nature, vol. 447, no. 7141, pp. 143-144, 2007.

[27] H. Song, Y. Liu, W. Xu et al., "Simultaneous Cr(VI) reduction and phenol degradation in pure cultures of Pseudomonas aeruginosa CCTCC AB91095," Bioresource Technology, vol. 100, no. 21, pp. 5079-5084, 2009.

[28] W. Shi, M. Bischoff, R. Turco, and A. Konopka, "Long-term effects of chromium and lead upon the activity of soil microbial communities," Applied Soil Ecology, vol. 21, no. 2, pp. 169-177, 2002.

[29] A. Johnson, G. Merilis, J. Hastings, M. E. Palmer, J. P. Fitts, and D. Chidambaram, "Reductive degradation of organic compounds using microbial nanotechnology," Journal of the Electrochemical Society, vol. 160, no. 1, pp. 0013-4651, 2013.

[30] D. Chidambaram, T. Hennebel, S. Taghavi et al., "Concomitant microbial generation of palladium nanoparticles and hydrogen to immobilize chromate," Environmental Science and Technology, vol. 44, no. 19, pp. 7635-7640, 2010.

[31] J. Fan, Y. Guo, J. Wang, and M. Fan, "Rapid decolorization of azo dye methyl orange in aqueous solution by nanoscale zerovalent iron particles," Journal of Hazardous Materials, vol. 166, no. 2-3, pp. 904-910, 2009.

[32] M. Otto, M. Floyd, and S. Bajpai, "Nanotechnology for site remediation," Journal of Remediation, vol. 19, no. 1, pp. 99-108, 2008.

[33] K. Z. Elwakeel, "Removal of Reactive Black 5 from aqueous solutions using magnetic chitosan resins," Journal of Hazardous Materials, vol. 167, no. 1-3, pp. 383-392, 2009.

[34] M. Greluk and Z. Hubicki, "Kinetics, isotherm and thermodynamic studies of reactive black 5 removal by acid acrylic resins," Chemical Engineering Journal, vol. 162, no. 3, pp. 919-926, 2010.

[35] Z. Aksu and G. Dönmez, "Combined effects of molasses sucrose and reactive dye on the growth and dye bioaccumulation properties of Candida tropicalis," Process Biochemistry, vol. 40, no. 7, pp. 2443-2454, 2005. 
[36] K. Vijayaraghavan and Y.-S. Yun, "Biosorption of C.I. Reactive Black 5 from aqueous solution using acid-treated biomass of brown seaweed Laminaria sp," Dyes and Pigments, vol. 76, no. 3, pp. 726-732, 2008.

[37] F. Y. Wang, H. Wang, and J. W. Ma, "Adsorption of cadmium (II) ions from aqueous solution by a new low-cost adsorbentBamboo charcoal," Journal of Hazardous Materials, vol. 177, no. 1-3, pp. 300-306, 2010.

[38] M. Antonopoulou, A. Giannakas, and I. Konstantinou, "Simultaneous photocatalytic reduction of $\mathrm{Cr}(\mathrm{VI})$ and oxidation of benzoic acid in aquous N-F-Codoped $\mathrm{TiO}_{2}$ suspension: optimization and modeling using the response surface methodology," International Journal of Photoenergy, vol. 2012, Article ID 520123, 10 pages, 2012.

[39] R. Sanghi, A. Dixit, and S. Guha, "Sequential batch culture studies for the decolorisation of reactive dye by Coriolus versicolor," Bioresource Technology, vol. 97, no. 3, pp. 396-400, 2006.

[40] N. Daneshvar, M. Ayazloo, A. R. Khataee, and M. Pourhassan, "Biological decolorization of dye solution containing Malachite Green by microalgae Cosmarium sp," Bioresource Technology, vol. 98, no. 6, pp. 1176-1182, 2007.

[41] E. Acuner and F. B. Dilek, "Treatment of tectilon yellow 2G by Chlorella vulgaris," Process Biochemistry, vol. 39, no. 5, pp. 623631, 2004

[42] L. Ai, C. Zhang, and Z. Chen, "Removal of methylene blue from aqueous solution by a solvothermal-synthesized graphene/magnetite composite," Journal of Hazardous Materials, vol. 192, no. 3, pp. 1515-1524, 2011.

[43] E. Forgacs, T. Cserháti, and G. Oros, "Removal of synthetic dyes from wastewaters: a review," Environment International, vol. 30, no. 7, pp. 953-971, 2004.

[44] S. Erdal and M. Taskin, "Uptake of textile dye reactive black5 by Penicillium chrysogenum MT-6 isolated from cementcontaminated soil," African Journal of Microbiology Research, vol. 4, no. 8, pp. 618-625, 2010.

[45] H. Wang, X.-W. Zheng, J.-Q. Su, Y. Tian, X.-J. Xiong, and T.-L. Zheng, "Biological decolorization of the reactive dyes Reactive Black 5 by a novel isolated bacterial strain Enterobacter sp. EC3," Journal of Hazardous Materials, vol. 171, no. 1-3, pp. 654-659, 2009.

[46] Z. Aksu, "Application of biosorption for the removal of organic pollutants: a review," Process Biochemistry, vol. 40, no. 3-4, pp. 997-1026, 2005.

[47] P. K. Malik, "Dye removal from wastewater using activated carbon developed from sawdust: adsorption equilibrium and kinetics," Journal of Hazardous Materials, vol. 113, no. 1-3, pp. 81-88, 2004.

[48] M. N. V. Prasad and H. M. De Oliveira Freitas, "Metal hyperaccumulation in plants-biodiversity prospecting forphytoremediation technology," Electronic Journal of Biotechnology, vol. 6, no. 3, pp. 110-146, 2003.

[49] M. A. Ashraf, M. J. Maah, and I. Yusoff, "Heavy metals accumulation in plants growing in ex tin mining catchment," International Journal of Environmental Science and Technology, vol. 8, no. 2, pp. 401-416, 2011.

[50] J. E. Tomaszewski, D. Werner, and R. G. Luthy, "Activated carbon amendment as a treatment for residual DDT in sediment from a superfund site in San Francisco Bay, Richmond, California, USA," Environmental Toxicology and Chemistry, vol. 26, no. 10, pp. 2143-2150, 2007.
[51] D. Woolf, J. E. Amonette, F. A. Street-Perrott, J. Lehmann, and S. Joseph, "Sustainable biochar to mitigate global climate change," Nature Communications, vol. 1, no. 5, 2010.

[52] D. D. Warnock, J. Lehmann, T. W. Kuyper, and M. C. Rillig, "Mycorrhizal responses to biochar in soil-concepts and mechanisms," Plant and Soil, vol. 300, no. 1-2, pp. 9-20, 2007.

[53] J. Major, C. Steiner, and A. Downie, "Biochar effects on nutrient leaching," in Biochar for Environmental Management: Science and Technology, Earthscan, London, UK, 3rd edition, 2009.

[54] J. M. Novak, W. J. Busscher, D. L. Laird, M. Ahmedna, D. W. Watts, and M. A. S. Niandou, "Impact of biochar amendment on fertility of a southeastern coastal plain soil," Soil Science, vol. 174, no. 2, pp. 105-112, 2009.

[55] X.-Y. Yu, G.-G. Ying, and R. S. Kookana, "Reduced plant uptake of pesticides with biochar additions to soil," Chemosphere, vol. 76, no. 5, pp. 665-671, 2009.

[56] Y. Yang and G. Sheng, "Enhanced pesticide sorption by soils containing particulate matter from crop residue burns," Environmental Science and Technology, vol. 37, no. 16, pp. 3635-3639, 2003.

[57] B. Wen, R.-J. Li, S. Zhang et al., "Immobilization of pentachlorophenol in soil using carbonaceous material amendments," Environmental Pollution, vol. 157, no. 3, pp. 968-974, 2009.

[58] X. Cao, L. Ma, Y. Liang, B. Gao, and W. Harris, "Simultaneous immobilization of lead and atrazine in contaminated soils using dairy-manure biochar," Environmental science \& technology, vol. 45, no. 11, pp. 4884-4889, 2011.

[59] R. J. Smernik, "Biochar and sorption of organic compounds," in Biochar for Environmental Management: Science and Technology, Earthscan, London, UK, 3rd edition, 2009.

[60] Y. Yang, G. Sheng, and M. Huang, "Bioavailability of diuron in soil containing wheat-straw-derived char," Science of the Total Environment, vol. 354, no. 2-3, pp. 170-178, 2006.

[61] G. Cornelissen, Ö. Gustafsson, T. D. Bucheli, M. T. O. Jonker, A. A. Koelmans, and P. C. M. Van Noort, "Extensive sorption of organic compounds to black carbon, coal, and kerogen in sediments and soils: mechanisms and consequences for distribution, bioaccumulation, and biodegradation," Environmental Science and Technology, vol. 39, no. 18, pp. 6881-6895, 2005.

[62] X. Han, L. Cheng-feng Liang, T. Li, K. Wang, and H. Huang $\mathrm{X}$ Yang, "Simultaneous removal of cadmium and sulfamethoxazole from aqueous solution by rice straw biochar," Journal of Zhejiang University Science B, vol. 102, no. 19, pp. 8877-8884, 2013.

[63] C.-T. Wang, "Photocatalytic activity of nanoparticle gold/iron oxide aerogels for azo dye degradation," Journal of NonCrystalline Solids, vol. 353, no. 11-12, pp. 1126-1133, 2007.

[64] A. Chen, G. Zeng, G. Chen et al., "Simultaneous cadmium removal and 2,4-dichlorophenol degradation from aqueous solutions by Phanerochaete chrysosporium," Applied Microbiology and Biotechnology, vol. 91, no. 3, pp. 811-821, 2011.

[65] X. Xu, X. Cao, L. Zhao, H. Wang, H. Yu, and B. Gao, "Removal of $\mathrm{Cu}, \mathrm{Zn}$, and $\mathrm{Cd}$ from aqueous solutions by the dairy manurederived biochar," Environmental Science and Pollution Research, pp. 1-11, 2012.

[66] X.-R. Xu, H.-B. Li, and J.-D. Gu, "Photocatalytic reduction of hexavalent chromium and degradation of Di-N-Butyl phthalate in aqueous $\mathrm{TIO}_{2}$ suspensions under ultraviolet light irradiation," Environmental Technology, vol. 28, no. 9, pp. 1055-1061, 2007. 
[67] J. C. Echeverría, M. T. Morera, C. Mazkiarán, and J. J. Garrido, "Competitive sorption of heavy metal by soils. Isotherms and fractional factorial experiments," Environmental Pollution, vol. 101, no. 2, pp. 275-284, 1998.

[68] O. R. Harvey, B. E. Herbert, R. D. Rhue, and L.-J. Kuo, "Metal interactions at the biochar-water interface: energetics and structure-sorption relationships elucidated by flow adsorption microcalorimetry," Environmental Science and Technology, vol. 45, no. 13, pp. 5550-5556, 2011.

[69] D. Zhang, B. Pan, H. Zhang, P. Ning, and B. Xing, "Contribution of different sulfamethoxazole species to their overall adsorption on functionalized carbon nanotubes," Environmental Science and Technology, vol. 44, no. 10, pp. 3806-3811, 2010.

[70] D. Zhu and J. J. Pignatello, "Characterization of aromatic compound sorptive interactions with black carbon (charcoal) assisted by graphite as a model," Environmental Science and Technology, vol. 39, no. 7, pp. 2033-2041, 2005.

[71] D. Zhu, S. Hyun, J. J. Pignatello, and L. S. Lee, "Evidence for $\pi-\pi$ electron donor-acceptor interactions between $\pi$-donor aromatic compounds and $\pi$-acceptor sites in soil organic matter through $\mathrm{pH}$ effects on sorption," Environmental Science and Technology, vol. 38, no. 16, pp. 4361-4368, 2004.

[72] R. J. E. Martins, R. Pardo, and R. A. R. Boaventura, "Cadmium(II) and zinc(II) adsorption by the aquatic moss Fontinalis antipyretica: effect of temperature, $\mathrm{pH}$ and water hardness," Water Research, vol. 38, no. 3, pp. 693-699, 2004.

[73] A. Mukherjee, A. R. Zimmerman, and W. Harris, "Surface chemistry variations among a series of laboratory-produced biochars," Geoderma, vol. 163, no. 3-4, pp. 247-255, 2011.

[74] X. Chen, G. Chen, L. Chen et al., "Adsorption of copper and zinc by biochars produced from pyrolysis of hardwood and corn straw in aqueous solution," Bioresource Technology, vol. 102, no. 19, pp. 8877-8884, 2011.

[75] Z. Liu and F.-S. Zhang, "Removal of lead from water using biochars prepared from hydrothermal liquefaction of biomass," Journal of Hazardous Materials, vol. 167, no. 1-3, pp. 933-939, 2009.

[76] R. Qiu, D. Zhang, Z. Diao et al., "Visible light induced photocatalytic reduction of $\mathrm{Cr}(\mathrm{VI})$ over polymer-sensitized $\mathrm{TiO}_{2}$ and its synergism with phenol oxidation," Water Research, vol. 46, no. 7, pp. 2299-2306, 2012.

[77] N. Wang, Y. Xu, L. Zhu, X. Shen, and H. Tang, "Reconsideration to the deactivation of $\mathrm{TiO} 2$ catalyst during simultaneous photocatalytic reduction of $\mathrm{Cr}(\mathrm{VI})$ and oxidation of salicylic acid," Journal of Photochemistry and Photobiology A: Chemistry, vol. 201, no. 2-3, pp. 121-127, 2009.

[78] W. Feng, D. Nansheng, and H. Helin, "Degradation mechanism of azo dye C. I. reactive red 2 by iron powder reduction and photooxidation in aqueous solutions," Chemosphere, vol. 41, no. 8, pp. 1233-1238, 2000.

[79] D. Wu, B. Pan, M. Wu, H. Peng, D. Zhang, and B. Xing, "Coadsorption of $\mathrm{Cu}$ and sulfamethoxazole on hydroxylized and graphitized carbon nanotubes," Science of the Total Environment, 2012.

[80] Y. Wan, Y. Bao, and Q. Zhou, "Simultaneous adsorption and desorption of cadmium and tetracycline on cinnamon soil," Chemosphere, vol. 80, no. 7, pp. 807-812, 2010.

[81] J. Chen, D. Zhu, and C. Sun, "Effect of heavy metals on the sorption of hydrophobic organic compounds to wood charcoal," Environmental Science and Technology, vol. 41, no. 7, pp. 25362541, 2007.
[82] W. WU, H. WANG, J. XU, and Z. XIE, "Adsorption characteristic of bensulfuron-methyl at variable added $\mathrm{Pb}^{2+}$ concentrations on paddy soils," Journal of Environmental Sciences, vol. 21, no. 8, pp. 1129-1134, 2009.

[83] F. Long, J.-L. Gong, G.-M. Zeng et al., "Removal of phosphate from aqueous solution by magnetic Fe-Zr binary oxide," Chemical Engineering Journal, vol. 171, no. 2, pp. 448-455, 2011.

[84] R. Dastjerdi and M. Montazer, "A review on the application of inorganic nano-structured materials in the modification of textiles: focus on anti-microbial properties," Colloids and Surfaces B: Biointerfaces, vol. 79, no. 1, pp. 5-18, 2010.

[85] V. K. K. Upadhyayula, S. Deng, M. C. Mitchell, and G. B. Smith, "Application of carbon nanotube technology for removal of contaminants in drinking water: a review," Science of the Total Environment, vol. 408, no. 1, pp. 1-13, 2009.

[86] K. Shankar, J. I. Basham, N. K. Allam et al., "Recent advances In the use of $\mathrm{TiO}^{2}$ nanotube and nanowire arrays for oxidative photoelectrochemistry," Journal of Physical Chemistry C, vol. 113, no. 16, pp. 6327-6359, 2009.

[87] B. Pan, H. Qiu, B. Pan et al., "Highly efficient removal of heavy metals by polymer-supported nanosized hydrated Fe(III) oxides: behavior and XPS study," Water Research, vol. 44, no. 3, pp. 815-824, 2010.

[88] A. M. G. C. Dias, A. Hussain, A. S. Marcos, and A. C. A. Roque, "A biotechnological perspective on the application of iron oxide magnetic colloids modified with polysaccharides," Biotechnology Advances, vol. 29, no. 1, pp. 142-155, 2011.

[89] A. K. Gupta and M. Gupta, "Synthesis and surface engineering of iron oxide nanoparticles for biomedical applications," Biomaterials, vol. 26, no. 18, pp. 3995-4021, 2005.

[90] M. A. Ashraf, K. Mahmood, A. Wajid, A. K. Qureshi, and M. Gharibreza, "Chemical constituents of Haloxylon salicornicum plant from Cholistan Desert, Bahawalpur, Pakistan," Journal of Food, Agriculture and Environment, vol. 11, no. 3-4, pp. 11761182, 2013.

[91] A. F. Abu Bakar, I. Yusoff, N. T. Fatt, F. Othman, and M. A. Ashraf, "Arsenic, zinc and aluminum removal from gold mine wastewater effluents and accumulation by submerged aquatic plants (Cabomba piauhyensis, Egeria densa, and Hydrilla verticillata)," BioMed Research International, vol. 2013, Article ID 890803, 7 pages, 2013.

[92] B. R. White, B. T. Stackhouse, and J. A. Holcombe, "Magnetic $\gamma$ - $\mathrm{Fe}_{2} \mathrm{O}_{3}$ nanoparticles coated with poly-l-cysteine for chelation of $\mathrm{As}(\mathrm{III}), \mathrm{Cu}(\mathrm{II}), \mathrm{Cd}(\mathrm{II}), \mathrm{Ni}(\mathrm{II}), \mathrm{Pb}$ (II) and $\mathrm{Zn}$ (II)," Journal of Hazardous Materials, vol. 161, no. 2-3, pp. 848-853, 2009.

[93] M. A. Ashraf, I. Yusoff, I. Yusof, and Y. Alias, "Removal of Cd (II) onto Raphanus sativus peels biomass: equlibrium, kinetics, and thermodynamics," Desalination and Water Treatment, vol. 51, no. 22-24, pp. 4402-4412, 2013.

[94] S. Singh, K. C. Barick, and D. Bahadur, "Surface engineered magnetic nanoparticles for removal of toxic metal ions and bacterial pathogens," Journal of Hazardous Materials, vol. 192, no. 3, pp. 1539-1547, 2011.

[95] Y. Pang, G.-M. Zeng, L. Tang et al., “Cr(VI) reduction by Pseudomonas aeruginosa immobilized in a polyvinyl alcohol/sodium alginate matrix containing multi-walled carbon nanotubes," Bioresource Technology, vol. 102, no. 22, pp. 1073310736, 2011.

[96] M. A. Ashraf, M. J. Maah, A. K. Qureshi, M. Gharibreza, and I. Yusoff, "Synthetic polymer composite membrane for the desalination of saline water," Desalination and Water Treatment, vol. 51, no. 16-18, pp. 3650-3661, 2013. 
97] S.-F. Niu, Y. Liu, X.-H. Xu, and Z.-H. Lou, "Removal of hexavalent chromium from aqueous solution by iron nanoparticles," Journal of Zhejiang University: Science, vol. 6, no. 10, pp. 10221027, 2005.

[98] Y.-M. Hao, C. Man, and Z.-B. Hu, "Effective removal of Cu (II) ions from aqueous solution by amino-functionalized magnetic nanoparticles," Journal of Hazardous Materials, vol. 184, no. 1-3, pp. 392-399, 2010.

[99] M. Baikousi, A. B. Bourlinos, A. Douvalis et al., "Synthesis and characterization of $\gamma-\mathrm{Fe}_{2} \mathrm{O}_{3}$ /carbon hybrids and their application in removal of hexavalent chromium ions from aqueous solutions," Langmuir, vol. 28, no. 8, pp. 3918-3930, 2012.

[100] P. Yuan, M. Fan, D. Yang et al., "Montmorillonite-supported magnetite nanoparticles for the removal of hexavalent chromium [Cr(VI)] from aqueous solutions," Journal of Hazardous Materials, vol. 166, no. 2-3, pp. 821-829, 2009.

[101] X. Lv, J. Xu, G. Jiang, and X. Xu, "Removal of chromium(VI) from wastewater by nanoscale zero-valent iron particles supported on multiwalled carbon nanotubes," Chemosphere, vol. 85, no. 7, pp. 1204-1209, 2011.

[102] Y. Li, Z. Jin, T. Li, and S. Li, "Removal of hexavalent chromium in soil and groundwater by supported nano zero-valent iron on silica fume," Water Science and Technology, vol. 63, no. 12, pp. 2781-2787, 2011.

[103] L. Wei, G. Yang, R. Wang, and W. Ma, "Selective adsorption and separation of chromium (VI) on the magnetic iron-nickel oxide from waste nickel liquid," Journal of Hazardous Materials, vol. 164, no. 2-3, pp. 1159-1163, 2009.

[104] A. R. Mahdavian and M. A.-S. Mirrahimi, "Efficient separation of heavy metal cations by anchoring polyacrylic acid on superparamagnetic magnetite nanoparticles through surface modification," Chemical Engineering Journal, vol. 159, no. 1-3, pp. 264-271, 2010.

[105] I. Yusoff, Y. Alias, M. Yusof, and M. A. Ashraf, "Assessment of pollutants migration at Ampar Tenang landfill site, Selangor, Malaysia," ScienceAsia, vol. 39, pp. 392-409, 2013.

[106] A. Pandikumar and R. Ramaraj, "Titanium dioxide-gold nanocomposite materials embedded in silicate sol-gel film catalyst for simultaneous photodegradation of hexavalent chromium and methylene blue," Journal of Hazardous Materials, vol. 203-204, pp. 244-250, 2012.

[107] R.-A. Doong, T.-C. Hsieh, and C.-P. Huang, "Photoassisted reduction of metal ions and organic dye by titanium dioxide nanoparticles in aqueous solution under anoxic conditions," Science of the Total Environment, vol. 408, no. 16, pp. 3334-3341, 2010.

[108] P. Wang and I. M. C. Lo, "Synthesis of mesoporous magnetic $\gamma$ $\mathrm{Fe}_{2} \mathrm{O}_{3}$ and its application to $\mathrm{Cr}(\mathrm{VI})$ removal from contaminated water," Water Research, vol. 43, no. 15, pp. 3727-3734, 2009.

[109] Q. Peng, Y. Liu, G. Zeng, W. Xu, C. Yang, and J. Zhang, "Biosorption of copper(II) by immobilizing Saccharomyces cerevisiae on the surface of chitosan-coated magnetic nanoparticles from aqueous solution," Journal of Hazardous Materials, vol. 177, no. 1-3, pp. 676-682, 2010.

[110] N. Tabassum, U. Rafique, K. S. Balkhair, and M. A. Ashraf, "Chemodynamics of methyl parathion and ethyl parathion: adsorption models for sustainable agriculture," Biomedical Research International, vol. 2014, Article ID 831989, 8 pages, 2014.

[111] H. Kyung, J. Lee, and W. Choi, "Simultaneous and synergistic conversion of dyes and heavy metal ions in aqueous $\mathrm{TiO}_{2}$ suspensions under visible-light illumination," Environmental Science and Technology, vol. 39, no. 7, pp. 2376-2382, 2005.

[112] S. Luo, Y. Xiao, L. Yang et al., "Simultaneous detoxification of hexavalent chromium and acid orange 7 by a novel $\mathrm{Au} / \mathrm{TiO}_{2}$ heterojunction composite nanotube arrays," Separation and Purification Technology, 2011.

[113] H. Shen and Y.-T. Wang, "Simultaneous chromium reduction and phenol degradation in a coculture of Escherichia coli ATCC 33456 and Pseudomonas putida DMP-1," Applied and Environmental Microbiology, vol. 61, no. 7, pp. 2754-2758, 1995.

[114] E. M. Nkhalambayausi-Chirwa and Y.-T. Wang, "Simultaneous chromium(VI) reduction and phenol degradation in a fixed-film coculture bioreactor: reactor performance," Water Research, vol. 35, no. 8, pp. 1921-1932, 2001.

[115] R. Singh, N. R. Bishnoi, A. Kirrolia, and R. Kumar, "Synergism of Pseudomonas aeruginosa and $\mathrm{Fe}^{0}$ for treatment of heavy metal contaminated effluents using small scale laboratory reactor," Bioresource Technology, vol. 127, pp. 49-58, 2013. 

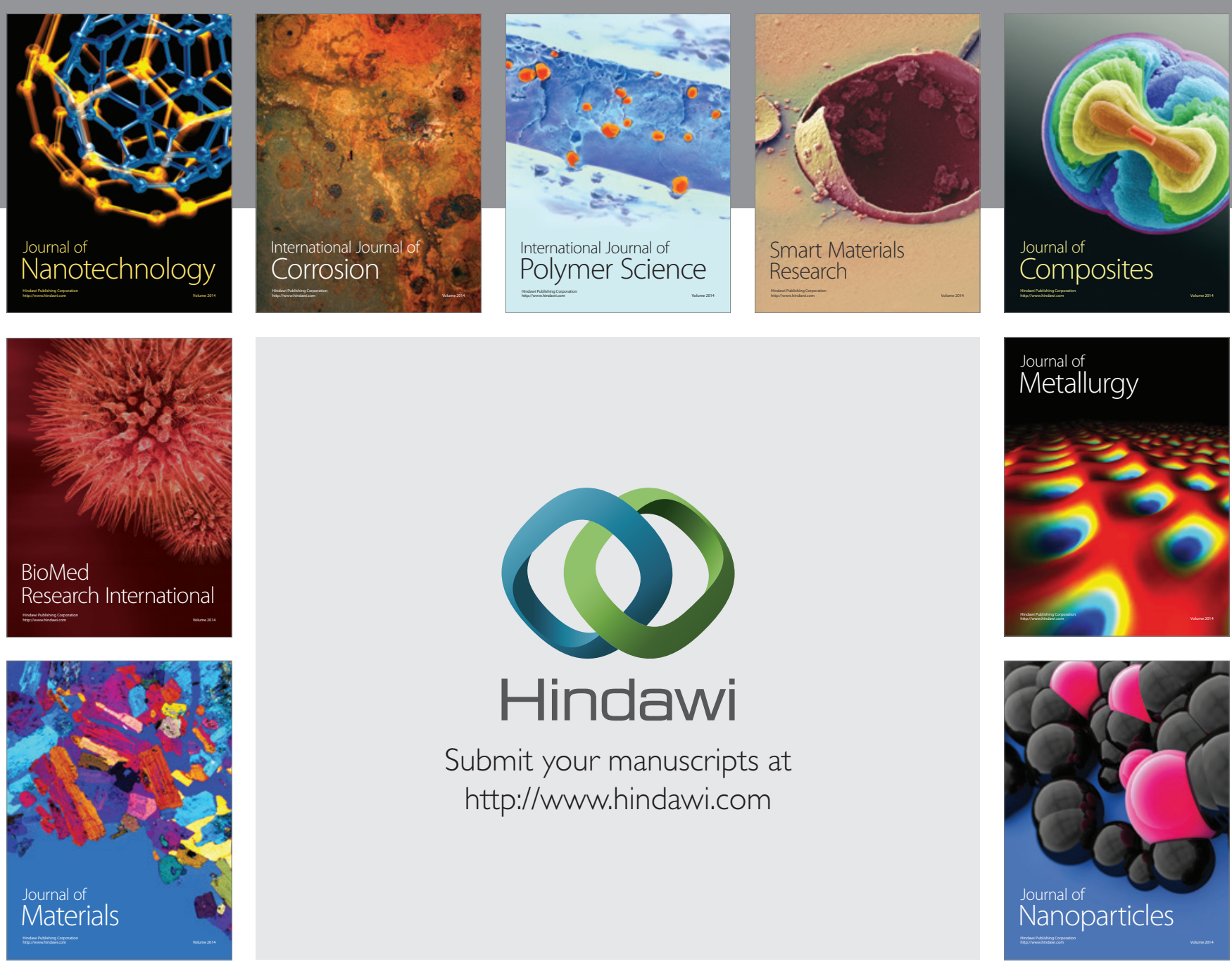

Submit your manuscripts at http://www.hindawi.com
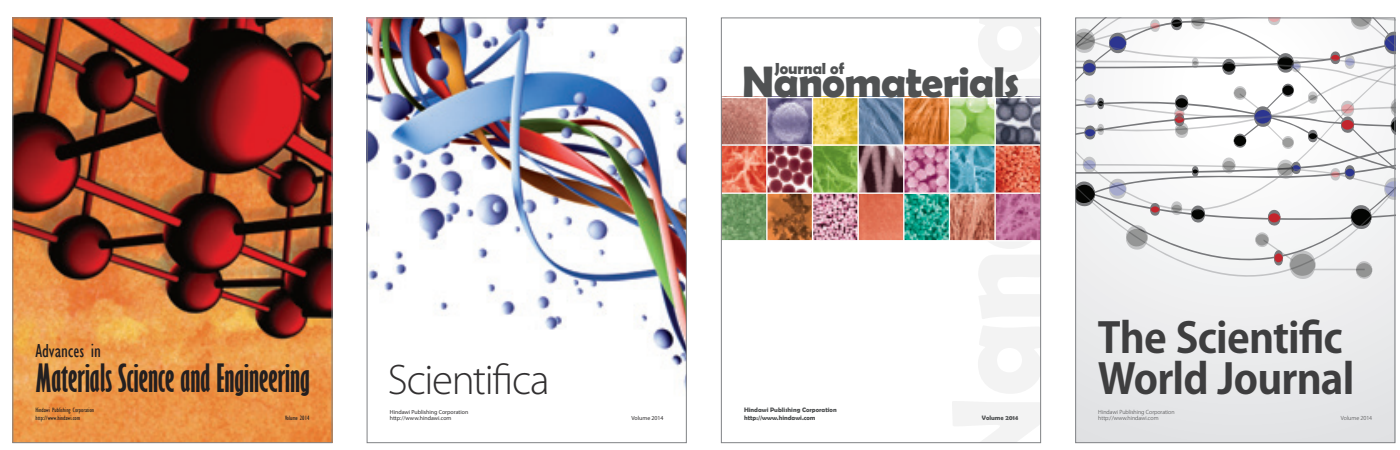

\section{The Scientific World Journal}
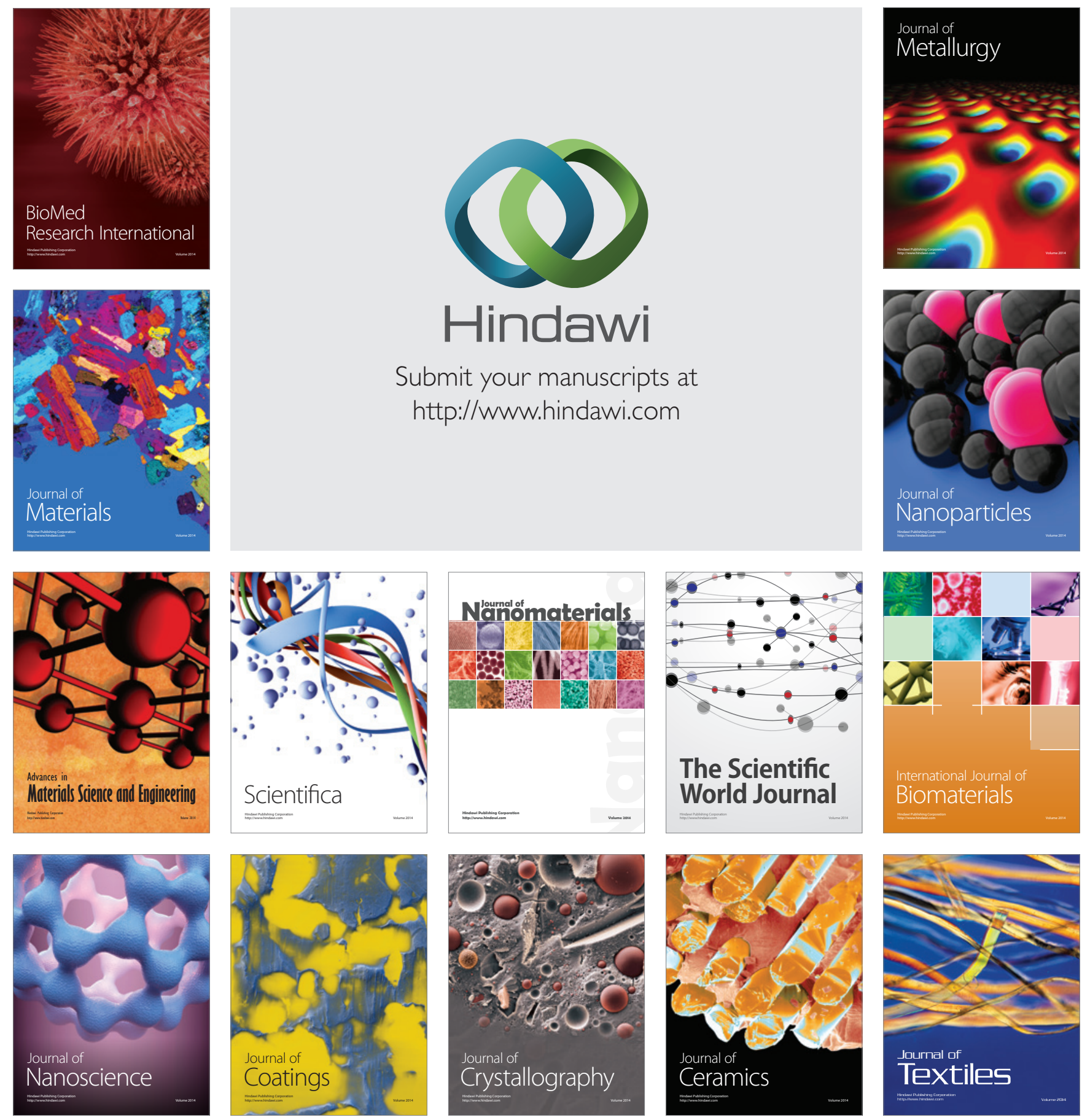